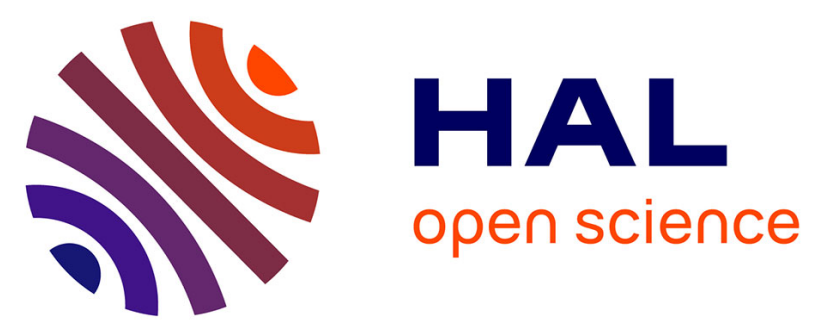

\title{
Air pollution modeling and exposure assessment during pregnancy in the French Longitudinal Study of Children (ELFE)
}

\author{
Emmanuel Riviere, Julien Bernard, Agnès Hulin, Jonathan Virga, Fabrice \\ Dugay, Marie-Aline Charles, Marie Cheminat, Jérôme Cortinovis, François \\ Ducroz, Anne Laborie, et al.
}

\section{To cite this version:}

Emmanuel Riviere, Julien Bernard, Agnès Hulin, Jonathan Virga, Fabrice Dugay, et al.. Air pollution modeling and exposure assessment during pregnancy in the French Longitudinal Study of Children (ELFE). Atmospheric Environment, 2019, 205, pp.103-114. 10.1016/j.atmosenv.2019.02.032 . ineris03319056

\section{HAL Id: ineris-03319056 \\ https://hal-ineris.archives-ouvertes.fr/ineris-03319056}

Submitted on 11 Aug 2021

HAL is a multi-disciplinary open access archive for the deposit and dissemination of scientific research documents, whether they are published or not. The documents may come from teaching and research institutions in France or abroad, or from public or private research centers.
L'archive ouverte pluridisciplinaire HAL, est destinée au dépôt et à la diffusion de documents scientifiques de niveau recherche, publiés ou non, émanant des établissements d'enseignement et de recherche français ou étrangers, des laboratoires publics ou privés. 
1 Air pollution modeling and exposure assessment during pregnancy in the French 2 Longitudinal Study of Children (ELFE)

3 Emmanuel Riviere $^{\mathrm{a}}$, Julien Bernard ${ }^{\mathrm{a}}$, Agnès Hulin ${ }^{\mathrm{b}}$, Jonathan Virga ${ }^{\mathrm{c}}$, Fabrice Dugay ${ }^{\mathrm{d}}$, Marie4 Aline Charles ${ }^{\mathrm{e}, \mathrm{f}}$, Marie Cheminat ${ }^{\mathrm{e}}$, Jérôme Cortinovis ${ }^{\mathrm{g}}$, François Ducroz ${ }^{\mathrm{h}}$, Anne Laborie ${ }^{\mathrm{i}}$, Laure $5 \quad$ Malherbe ${ }^{\mathrm{j}}$, Damien Piga ${ }^{\mathrm{c}}$, Elsa Real ${ }^{\mathrm{j}}$, Pierre-Yves Robic ${ }^{\mathrm{k}}$, Cecile Zaros ${ }^{\mathrm{e}}$, Emie Seyve ${ }^{\mathrm{l}}$, Johanna 6 Lepeule $^{1}$

7

${ }^{a}$ ATMO Grand Est, France

bATMO Nouvelle-Aquitaine, France

${ }^{\mathrm{c}}$ ATMO Sud, France

${ }^{\mathrm{d}}$ AIRPARIF, France

${ }^{\mathrm{e}}$ Ined-Inserm-EFS joint unit Elfe, Paris, France

${ }^{\mathrm{f}}$ Inserm Univ Paris Descartes, U1153 CRESS, Paris, France

${ }^{\mathrm{g}}$ ATMO Normandie, France

${ }^{\mathrm{h}}$ AIR Pays-de-la-Loire, France

${ }^{\mathrm{i}}$ ATMO France, France

${ }^{\mathrm{j}}$ National Institute for industrial Environment and Risks (INERIS), Verneuil en Halatte, France

${ }^{\mathrm{k}}$ ATMO Occitanie, France

${ }^{1}$ Univ. Grenoble Alpes, Inserm, CNRS, IAB, 38000 Grenoble, France

Correspondence to Johanna LEPEULE, Johanna.lepeule@univ-grenoble-alpes.fr

Phone : +33476549466

Team of Environmental Epidemiology Applied to Reproduction and Respiratory Health

Inserm U1209 / CNRS UMR 5309 / Univ. Grenoble Alpes joint research center

Institute for Advanced Biosciences

Site Santé, Allée des Alpes, 38700 La tronche, France 


\section{Abstract}

We developed a nation-wide exposure model to $\mathrm{NO}_{2}, \mathrm{PM}_{10}$ and $\mathrm{PM}_{2.5}$ at a fine spatial and temporal resolution for France in order to study air pollutants exposure during pregnancy for the French Longitudinal Study of Children (ELFE).

The exposure to air pollutants was estimated daily for years 2010 and 2011 by combining three simulation models at the national and regional scale (CHIMERE) and at the local urban scale (ADMS-Urban or SIRANE). The spatial resolution was $4 \mathrm{~km}$ for the national scale model, 3 to 4 $\mathrm{km}$ for regional models and from 10 to 200 meters for urban-scale models. We developed a confidence index (from 0 to 10 ) based on the target plot to identify the best model to estimate exposure for a given address, year and pollutant. Air pollution exposure during pregnancy was then estimated using each modeling scale for the 17,427 women participating in the ELFE cohort. We described the exposure of the women during different time windows of pregnancy using each of the three models and using the most suitable model as estimated by the confidence index. The exposure estimates obtained from the three models were quite similar and highly correlated (spearman correlation between 0.64 and 0.96), especially for the national and regional models. For $\mathrm{NO}_{2}$ and $\mathrm{PM}_{10}$ predicted by the urban models, the minimum values were lower and the maximum values and the variability were higher, compared to the regional and national models. The averaged confidence indexes were comprised between 5.6 and 8 depending on the pollutant, year and exposure model considered. The best confidence index was observed for urban modeling (10) and the lowest for the regional modeling (0). In average during pregnancy, using the most suitable model, women were exposed to $21 \mu \mathrm{g} / \mathrm{m}^{3}$ for $\mathrm{NO}_{2}, 16 \mu \mathrm{g} / \mathrm{m}^{3}$ for $\mathrm{PM}_{2.5}$ and 24 $\mu \mathrm{g} / \mathrm{m}^{3}$ for $\mathrm{PM}_{10}$.

To our knowledge, this is the first study combining three modeling tools available at different scales to estimate $\mathrm{NO}_{2}, \mathrm{PM}_{10}$ and $\mathrm{PM}_{2.5}$ concentrations at a fine spatial and temporal resolution over a large geographical area. The confidence index provides guidance in the choice of the exposure model. These exposure estimates will be used to investigate potential effects of air pollutants on the pregnant woman health and on health of the fetus and development of the child.

\section{Keywords}

Cohort, air pollution, dispersion modeling, exposure assessment, pregnancy 


\section{Introduction}

A large body of literature has been published in the last 20 years about the relationship between maternal exposure to air pollutants and pregnancy outcomes, including pre-eclampsia, fetal growth, and gestational duration (Pedersen et al., 2013; 2014; Shah et al., 2011). The contribution of maternal exposure to air pollutants to child's respiratory health (Korten et al., 2017), metabolic diseases (Lavigne et al., 2016), or neurodevelopmental disorders (Clifford et al., 2016; Xu et al., 2016) is an area of growing interest. Yet, little is known about the lasting influences of in utero exposure to air pollutants on child health.

Air quality monitoring stations provide a high temporal resolution, usually hourly or daily measures, but their spatial resolution is poor due to the low density of monitors for a usually large area of study. Thus using air quality monitors for exposure assessment is subject to measurement error. The last 10 years have seen a rapid development of air quality modeling (Oliveri Conti et al., 2017). Models with fine spatial resolution have been implemented including dispersion models or land-use regressions, the most used in epidemiological studies, sometimes combined with geostatistical techniques. Most often, these models are developed for a few cities and focus on the most urbanized areas (Eeftens et al., 2012; Sellier et al., 2014). Annual estimates are usually provided (Eeftens et al., 2012), although some models may produce sub-annual predictions (Sellier et al., 2014).

As part of a study on the effects of early exposure to air pollutants on pregnancy outcomes and child's health (the PATer project "Pollution Atmosphérique sur le territoire français: modélisation et effets sanitaires") in the ELFE cohort (The French Longitudinal Study of Children) (Vandentorren et al., 2009), we aimed to develop a nation-wide exposure model to $\mathrm{NO}_{2}, \mathrm{PM}_{10}$ and $\mathrm{PM}_{2.5}$, with daily estimates in 2010 and 2011 (the time period covering the pregnancies of the ELFE cohort women) and a fine spatial resolution for France. We describe the development of air quality models at the national, regional and local scale, and the development of a confidence index based on the target plot (Thunis et al., 2013), which was used to identify the best model for a given address, year and pollutant. The exposure of the women participating in the ELFE cohort are described for each modeling scale and for the best model as estimated by the confidence index. A specific challenge of the project was to bring together about 25 organizations able to produce air quality data from numerical simulations on a large number of urban areas of metropolitan France, but also at regional and national scale. 


\section{Methods}

\subsection{Population studied}

The French Longitudinal Study of Children (ELFE, https://www.elfe-france.fr/en/) is a prospective birth cohort recruited in 2011 and designed to collect data on the health and development of children, their family, socio-cultural, nutritional and environmental factors from conception to 20 years of age. Women giving birth in one of the 344 randomly selected maternity wards (out of 540) in metropolitan France during the 4 enrollment periods (April 1st -4th; June 27th-July 4th; September 27th-October 4th; November 28th-December $5^{\text {th }}$ ) were invited to participate. Multiple births of three children or more, very preterm births (before 33 weeks of gestation), mothers under age 18, mothers who did not read French, Arabic, Turkish or English, mothers unable to give informed consent, or who planned to move abroad within three years were not eligible. Finally, 18329 children and their mothers were included. Home addresses of the women during pregnancy and of the children after birth were collected and geocoded, but for 902 women, geocoded address was not available. Therefore our analysis included 17427 women for whom at least one geocoded address during pregnancy was available (Figure 1). All participating women gave informed consent to participate in the study. The ELFE study was approved by the relevant ethical committees (CNIL, Commission nationale de l'informatique et des libertés; CCTIRS, Comité Consultatif sur le traitement de l'Information en matière de Recherche dans le domaine de la Santé; CNIS, Conseil National de l'Information Statistique). 


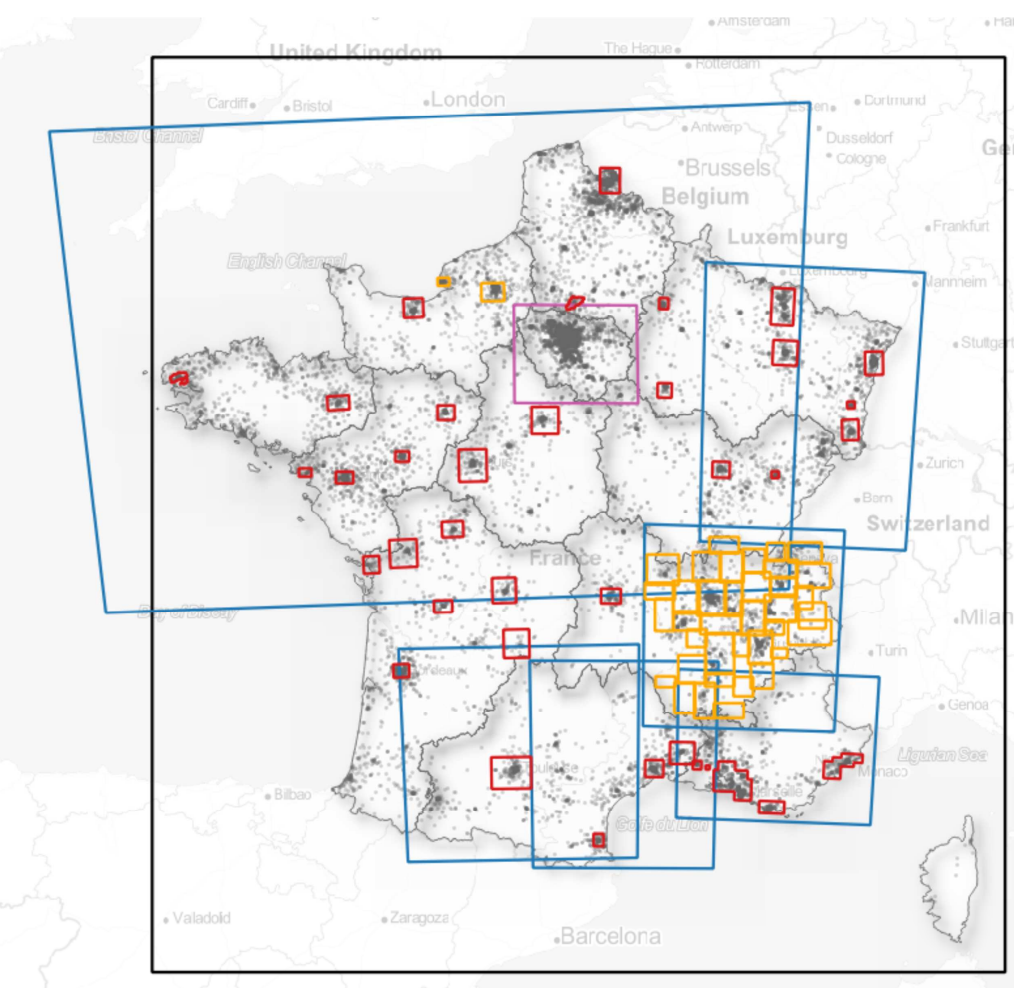

Home addresses of ELFE women at delivery and models covering the metropolitan France at different scales

$\square$ Urban modeling (ADMS - Urban)

Urban and Inter urban modeling (SIRANE)

$\square$ Urban modeling (STREET)

$\square$ Regional modeling (CHIMERE/WRF or CHIMERE/MM5)

$\square$ National modeling (CHIMERE/IFS)

Home addresses of the 17427 ELFE cohort women Source ELFE - database PANDORA

Figure 1: Home addresses of ELFE pregnant women at delivery and models covering the metropolitan France at different scales

\subsection{Study area}

We studied the metropolitan area of France (excluding Corsica island), which represents about $551,695 \mathrm{~km}^{2}$ with a population of $65,058,000$.

\subsection{Modeling strategy}

The characterization of exposure to air pollution is based on three simulation models at the national, regional and local scale (Figure 1). The national CHIMERE chemistry-transport model (Mailler et al., 2017; Menut et al., 2013; Valari et al., 2011) is used to estimate air pollution levels for the metropolitan France, with a resolution of $4 \mathrm{~km} \mathrm{x} 4 \mathrm{~km}$. This model has long been run and evaluated in France as the main component of the national air quality forecasting and monitoring system PREV'AIR (Honoré et al., 2008). It is also implemented across several regional areas with resolution of $3 \mathrm{~km} \mathrm{x} 3 \mathrm{~km}$ or $4 \mathrm{~km} \mathrm{x} 4 \mathrm{~km}$, depending on the regional area. In urban areas, air pollution levels are estimated by urban-scale models which are currently implemented on most agglomerations $>250,000$ inhabitants (20 out of 24), but also in smaller 
agglomerations (23 out of 31 agglomerations with more than 100,000 inhabitants), with a very high spatial resolution from ten to two hundred meters. The quasi-Gaussian Atmospheric Dispersion Modeling System (ADMS) Urban (Cambridge Environmental Research Consultants, Cambridge, United Kingdom (Carruthers et al., 2000a)) or the SIRANE model (Soulhac et al., 2017 ; 2011; 2012b) are widely used in France as part of or to supplement the regulatory monitoring of air quality. The use of ADMS-urban and SIRANE is supported by validation studies ((Carruthers et al., 2000b; Stocker et al., 2012), for ADMS-Urban, https://www.cerc.co.uk/environmental-software/model-validation.html, Soulhac et al., 2017 for SIRANE) and comparison studies (inter-model and inter-laboratory comparisons) organized by the national reference laboratory (Wroblewski et al. 2009 ; Malherbe et al., 2010 ; Tognet et al., 2016).

\subsubsection{Input data}

Three types of input data were used. National and local emission inventories came from the European Monitoring and Evaluation Program emission cadaster (http://www.emep.int/index.html) (Figure 2). The local inventories are mainly based on the national coordination pole guidebook to ensure methodological consistency across local inventories (Pôle national de coordination des inventaires territoriaux, 2012). Meteorological data were provided by the Integrated Forecast System (IFS) data re-analyzed for the national model, coupling with the MM5 model for the great north-west zone. For regional modeling tools, NCEP FNL Operational Global Analysis data were used with the WRF or MM5 model. For urban tools, observed data were provided by Meteo-France. Boundary conditions were collected from a European dataset provided by CHIMERE France - European scale for the national model and from the measurement network observations (background monitors) for urban-scale models. 


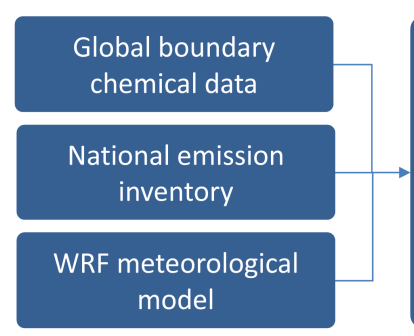

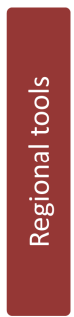
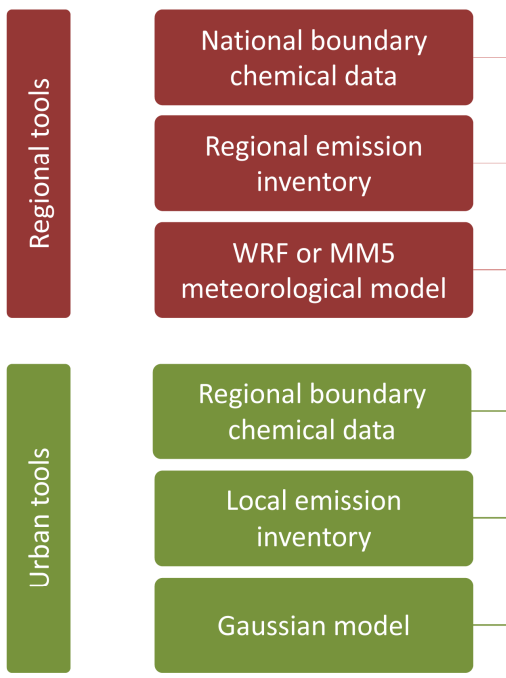

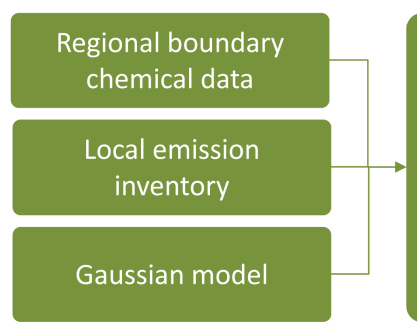

Run1 : NO $\mathrm{NM}_{10}, \mathrm{PM}_{2,5}$

At each address with

hourly concentrations

Run2 : $\mathrm{NO}_{2}, \mathrm{PM}_{10}, \mathrm{PM}_{2,5}$

Gridded with high

resolution $(10-200 \mathrm{~m})$ and

annual concentrations
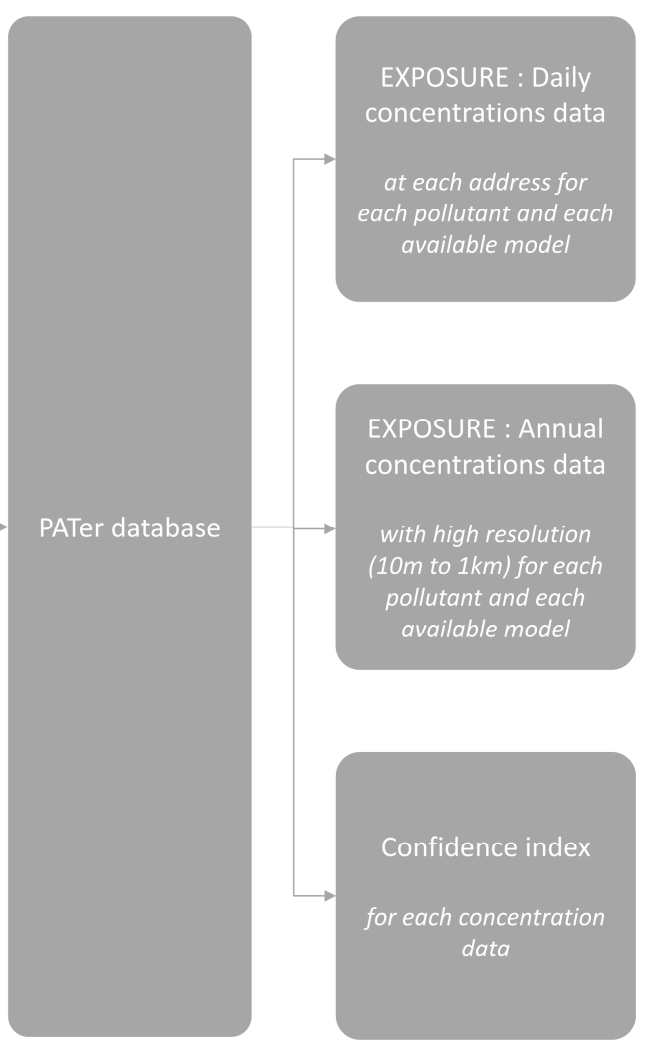

Figure 2: Diagram of the modeling strategy

\subsubsection{Computations}

Simulation runs were performed on the national, regional and urban scales to predict concentrations of nitrogen dioxyde $\left(\mathrm{NO}_{2}\right)$, particulate matter $\left(\mathrm{PM}_{10}\right.$ and $\left.\mathrm{PM}_{2.5}\right)$, ozone $\left(\mathrm{O}_{3}\right)$, sulfur dioxide $\left(\mathrm{SO}_{2}\right)$ and benzene $\left(\mathrm{C}_{6} \mathrm{H}_{6}\right)$ for years 2010 and 2011 .

On national and regional scales, hourly simulations were performed on regular grids of 3 to $4 \mathrm{~km}$ resolution. In a second stage, statistical or geostatistical approaches were applied to refine the modeling results and produce the most realistic concentration fields. On the national scale, model outputs and measurements from the permanent monitoring network were thus combined by external drift kriging (Malherbe 2009; Benmerad et al., 2017). In addition for $\mathrm{NO}_{2}$, $\mathrm{NOx}$ emission data from the national emission inventory were introduced as an auxiliary variable into the kriging to better account for concentration gradients in the vicinity of emission sources. An estimation grid mesh of $1 \mathrm{~km}$ was used for $\mathrm{NO}_{2}$ and $\mathrm{PM}_{10}$ pollutants (and by homogeneity $\mathrm{PM}_{2,5}$ ) considering the resolution of NOx emission data and the spatial density of measurements in some urban areas whereas the initial grid resolution of $4 \mathrm{~km}$ was kept for ozone due to its more 
regional nature. Kriging-based or optimal interpolation methods were also applied on the regional scale to combine model outputs and observation data. In some regions, a mesh refinement technique was implemented to improve the accuracy of the modeling results and increase the resolution of the calculation efficiently. It interpolates the result of a pollutant concentration calculation on a finer mesh based on physical and physiographic principles governing the spatial differentiation of concentrations. This method makes it possible to highlight the concentration gradients near the sources of emissions. In concrete terms, the technique is based on the interpolation of a 3D field of a coarse mesh grid on a fine mesh grid, based on topology data and emissions (at a 1 x $1 \mathrm{~km}$ resolution).

On the urban scale, because of the high volume of data and the high computation time that is needed for generating hourly predictions, two types of outputs were considered: the first one consisted in hourly predictions of pollutant concentrations at each of the 17,427 addresses of the ELFE cohort for the specific needs of the project; the second one consisted in annual average predictions of pollutants concentrations on a grid, allowing reuse of data for other epidemiological studies. Depending on the characteristics and configuration of the modeling tools, different simulation grids were defined: usually a regular grid for SIRANE and an irregular one, sparse in background areas and denser close to roads and emission sources for ADMS Urban. In that second case annual modeling results were interpolated on a fine regular grid using interpolation techniques (Beauchamp et al., 2014).

The final spatial resolution of the concentration maps after post-processing is 1 to $4 \mathrm{~km}$ for the national scale model, $1 \mathrm{~km}$ for regional models and 10 to 200 meters for urban-scale models for annual concentrations.

\subsubsection{Validation and indicators of quality of the models}

Validation of the models was performed by comparing the predicted concentrations to the concentrations measured by the network of permanent air quality monitors using the Delta Tool methodology (Pernigotti et al., 2013; Thunis et al., 2013; Thunis and Cuvelier, 2016; Thunis et al., 2012). This method has been developed by the European Joint Research Center (JRC) within FAIRMODE (http://fairmode.jrc.ec.europa.eu) to perform diagnostics of air quality and meteorological model performances. Model performance assessment includes in particular the socalled Target Plot (Figure 3). This diagram is a representation of the Modeling Quality Indicator 
(MQI), a statistical indicator which describes the discrepancy between modeling results and measurements, taking the measurement uncertainty into account. The MQI combines different statistical scores: CRMSE - Centered Root Mean Square Error, R - Correlation coefficient, SD Standard Deviation, NMB - Normalised Mean Bias (Figure 3). The modeling quality objective (MQO) is the quality criterion associated to the MQI. It is considered as fulfilled if the MQI is less than or equal to unity (points inside the circle of the Target Plot, Figure 3).

In the present project, the target plots were calculated for each of the three modeling scales using daily averaged concentrations. Predicted concentrations of each model have been compared to all the measurements of permanent monitors included in the modeled area. For the national and regional models, which combine CHIMERE outputs with measurements from rural and urban background monitors (see previous section), the target plots for background stations were calculated using a leave-one-out cross validation approach so that the resulting estimates and the measurements were independent and could be compared. For traffic stations (which are not used in the kriging), the target plots were calculated by interpolating the model results at the monitoring points. Higher MQI was logically obtained at those sites since the national and regional models are not intended to finely reproduce traffic-related concentration levels. As for the urban models, the performance of the modeling could not be as precisely characterized than for the national and regional models since there is a lack of measurement stations in some urban areas, with only one or two monitors for each pollutant. It can be observed that the points representing the model performance at each station tend to be located on the left part of the diagram (i.e. CRMSE error dominated by correlation, figure 3), which could be explained by a very high dynamic of pollution levels not precisely taken into account by the emission inventory at the point of the station. 

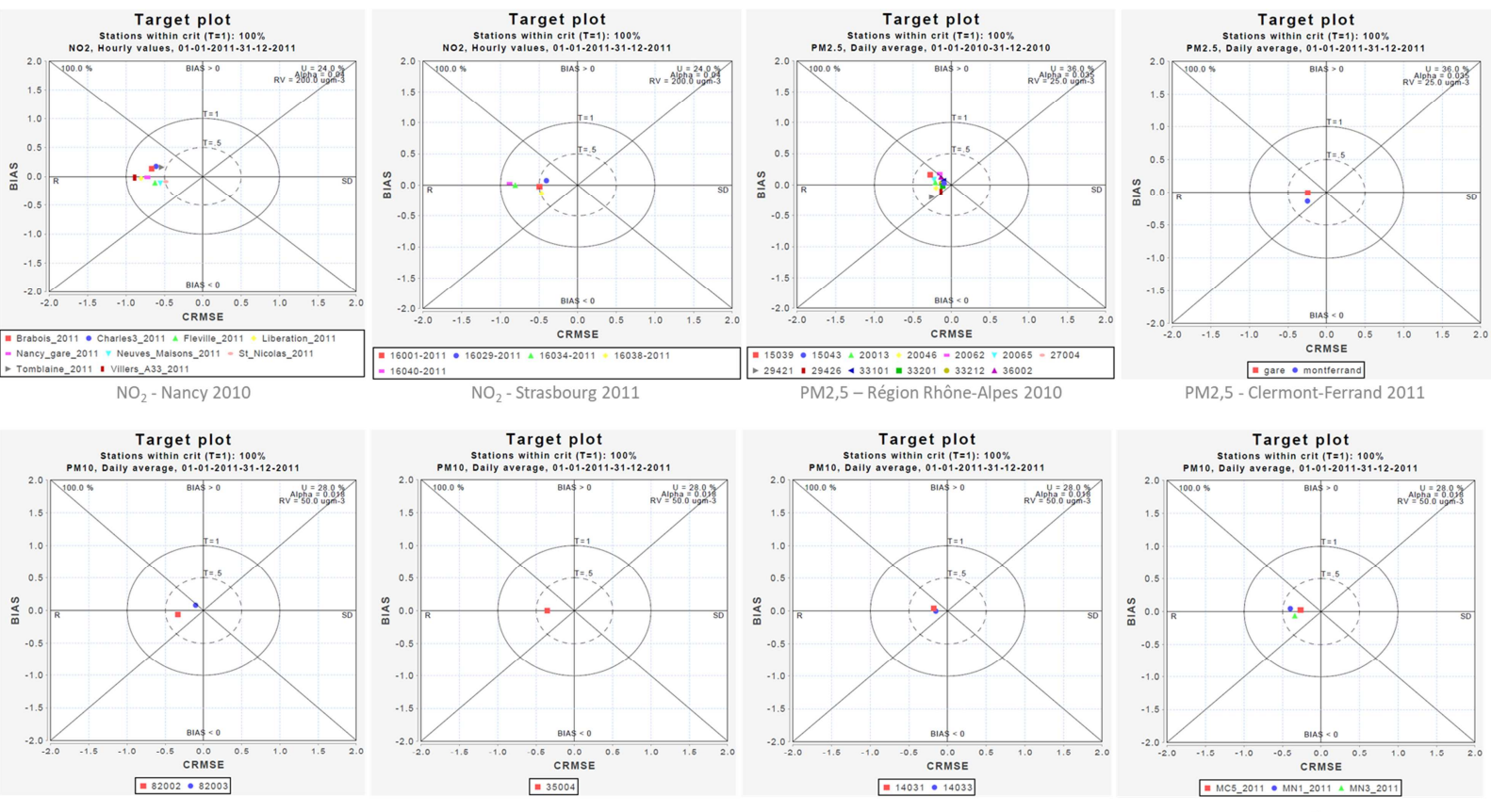

PM10 - Besançon 2011

PM10 - Brive 2011

PM10 - Troyes 2011

PM10 - Lille 2011

Figure 3: Example of target plots for urban models for different cities, years, and pollutants

2.4. Pregnancy exposures

We estimated air pollutants exposure of pregnant women according to each of the three models (national, regional and urban scale) for short- and long-term time windows during pregnancy including: whole pregnancy, each trimester of pregnancy, each month, each week and the 30 last days of pregnancy. Therefore, for each woman and each time-window, up to three different concentrations were available from the national, regional and urban-scale models. Exposure for time windows with more than $25 \%$ of missing values was not estimated.

\subsection{Confidence index}

In order to help the epidemiologists to choose the most relevant exposure model, we calculated a confidence index (C) based on the Model Quality Index (MQI). The MQI provides insight into the quality of the model average performances (Thunis and Cuvelier, 2016). The MQI varies on a scale from 0 to infinite, between the origin of the Target Plot $(0,0)$ and the position of the measuring station for which concentrations have been calculated with the model (Figure 3). The closer the station's position is to the origin, the lower the MQI and the better the modeling are (Figure 4). 

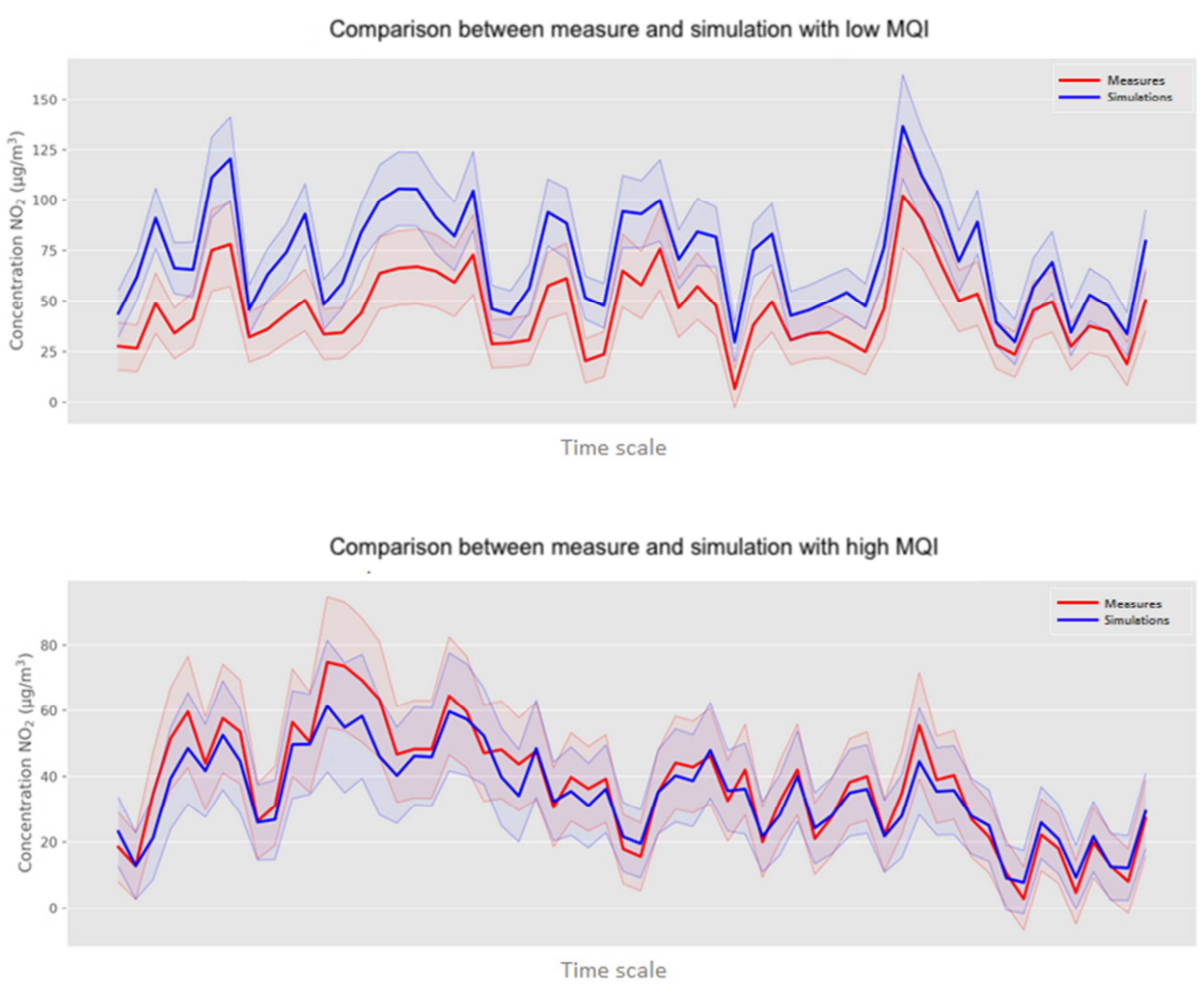

Figure 4: Comparison between measurements from a station and predictions from a model for a high and low Model Quality Index (MQI).

For proper comparisons of the quality of the estimates from the three models, the statistics compared across models should be on the same scale. Therefore, we calculated a Confidence index (C), which converts the result of the MQI (from 0 to infinite) to a value between 0 and 10 using the following equation: $\mathrm{C}=-6 \mathrm{x} \mathrm{MQI}+10$ with 10 being the best $\mathrm{C}$ (reached when the MQI is 0 ) indicating a perfect modeling result. On the contrary, for a MQI of 1 the $\mathrm{C}$ will be 4 . A $\mathrm{C}$ with a value of 0 (bad confidence) will be reached for a MQI of about 1.67 .

For the urban scale models, model performance was assumed to be homogeneous according to the type of location (i.e. background or traffic). The MQI was calculated for each measurement station and was then averaged separately for background and traffic stations, leading to two types of confidence index (C) depending on distance to traffic. A woman located close to traffic (i.e. in a $200 \mathrm{~m}$ buffer around motorway type roads, or in a $150 \mathrm{~m}$ buffer around a main link road, or in a $100 \mathrm{~m}$ buffer around a regional link road) was assigned the average confidence index calculated 
for near traffic monitors, whereas in other locations she was assigned the average confidence index calculated for background monitors. For the national and regional scale models, model performance was assumed to be more variable across the modeling domain. The MQI was calculated for each monitor as described in section 2.3.3. The MQI and the corresponding confidence index at each background (resp. near-traffic) address of the ELFE cohort women were then calculated by interpolating the MQI of all the available background (resp. traffic) measurement monitors using the inverse-distance weighting method between the address of the woman and the location of the monitors.

Since the spatial coverage of monitors is limited (497 monitors for $\mathrm{NO}_{2}$ (297 background, 200 traffic), 390 for $\mathrm{PM}_{10}$ (223 background, 167 traffic) and 106 for $\mathrm{PM}_{2.5}$ (64 background, 42 traffic)), the Target Plot, MQI and C calculated do not account for the high spatial variability of air pollutants concentrations (especially for $\mathrm{NO}_{2}$ ) and therefore for the potential variability of model performances. This high spatial variability in concentrations captured by urban-scale models (Figure 5) is a major asset of these models when one is interested in the local variations of exposure. This is illustrated in Supplemental Figure S1, which shows that smoothing concentrations on a kilometer grid obviously leads to a decrease in the accuracy of the concentrations near the main roads, better represented on a metric grid. Indeed, in the urban modeling tools, road emissions are precisely entered into the model while they are diluted on meshes of several square kilometers in the national and regional models. In our study, among the 17,427 addresses, $33 \%$ were located close to traffic. The urban models allow to account for the variability of concentrations near traffic. They are implemented with final spatial resolutions ranging from 10 (near sources) to 200 meters and are more adapted to the complexity of air pollutants sources in the cities than the regional or national models. Therefore, if an urban model exists, this one will be favored compared to the other scales, irrespectively of the confidence index, to provide the value of exposure of the ELFE women during pregnancy. 

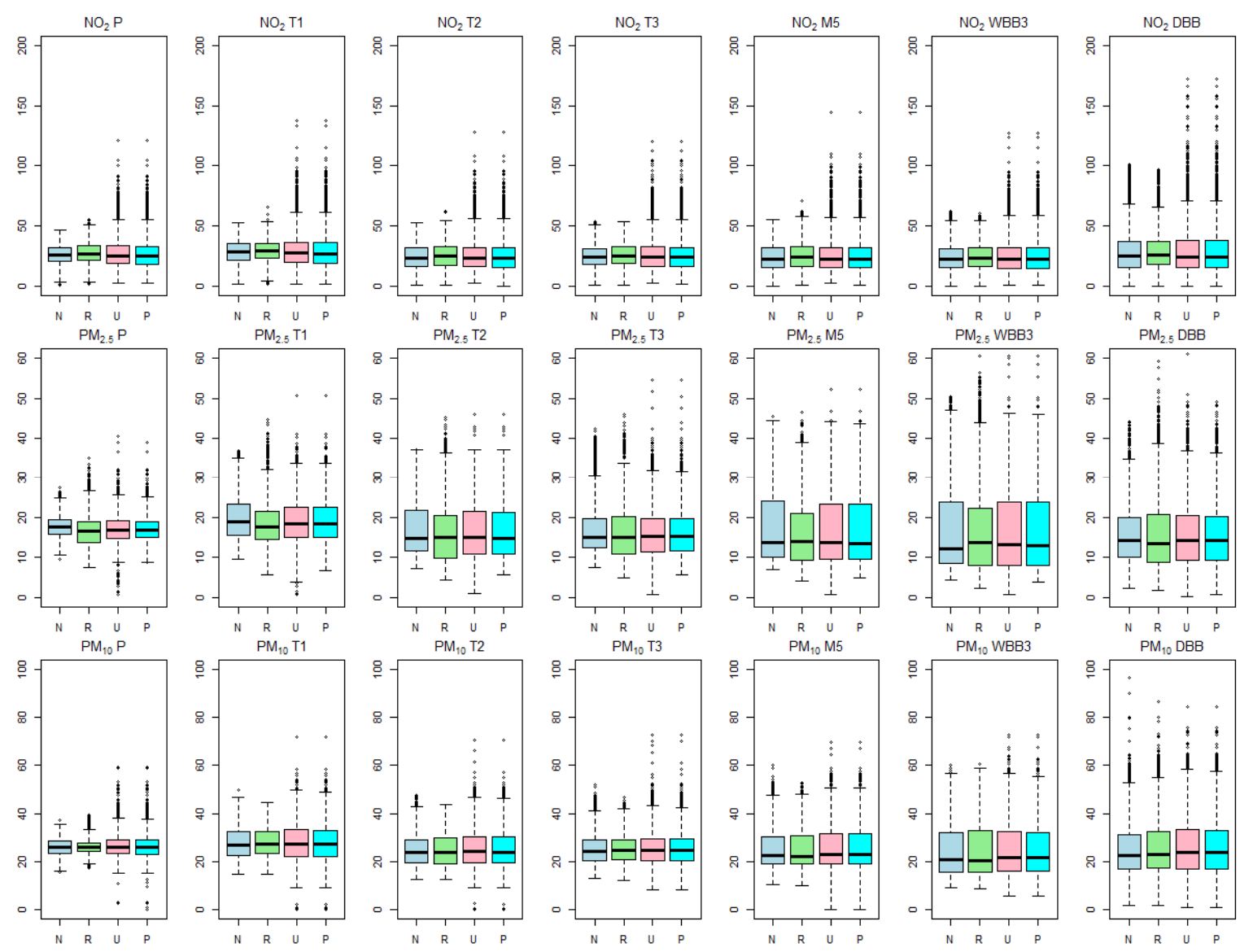

P: Pregnancy, T1: trimester 1, T2: trimester 2, T3: trimester 3, M5: month 5, WBB3: $3^{\text {rd }}$ week before birth , DBB: day before birth, N: National model, R: Regional model, U: Urban model, P: PATer estimate (i.e. the most suitable model: the urban model if there is one, the model which has the highest confidence index among the regional and national model).

Figure 5: Distribution of exposures during pregnancy as estimated by each of the 3 models and by the final PATer most suitable estimate, for all women covered by the 3 models

\subsection{Statistical analyses}

Coverage of the study area was heterogeneous for $\mathrm{O}_{3}, \mathrm{SO}_{2}$ and $\mathrm{C}_{6} \mathrm{H}_{6}$. We therefore focused our analyses on $\mathrm{NO}_{2}, \mathrm{PM}_{2.5}$ and $\mathrm{PM}_{10}$. We described pregnant women's exposures and their confidence index using each of the three models (national, regional and urban-scale) for the following time windows: pregnancy, each trimester of pregnancy, fifth month of pregnancy, third week before birth and day before birth. Then, for the sub-sample of women covered by the 3 
models, we compared their exposures and confidence indexes as estimated by the 3 models and the final exposures as estimated by the most suitable model (i.e. the urban model if there is one, the model which has the highest confidence index among the regional and national model). For simplicity, this final exposure is hereinafter called the PATer (from the name of the project) estimate. Spearman correlation coefficients between the 3 models and the PATer estimates were calculated.

\section{Results}

\subsection{Pregnancy exposures as estimated by each of the $\mathbf{3}$ models}

$\mathrm{NO}_{2}$ exposures during pregnancy as estimated by the national, regional and urban models are represented in figure 6. Depending on the exposure model used, women in the ELFE cohort were exposed on average during pregnancy between 20 and $26 \mu \mathrm{g} / \mathrm{m}^{3}$ for $\mathrm{NO}_{2}, 16$ and $17 \mathrm{for} \mu \mathrm{g} / \mathrm{m}^{3}$ for $\mathrm{PM}_{2.5}$ and 24 and $25 \mu \mathrm{g} / \mathrm{m}^{3}$ for $\mathrm{PM}_{10}$ (Table 1). These average values were quite similar for exposure during the other time windows studied.

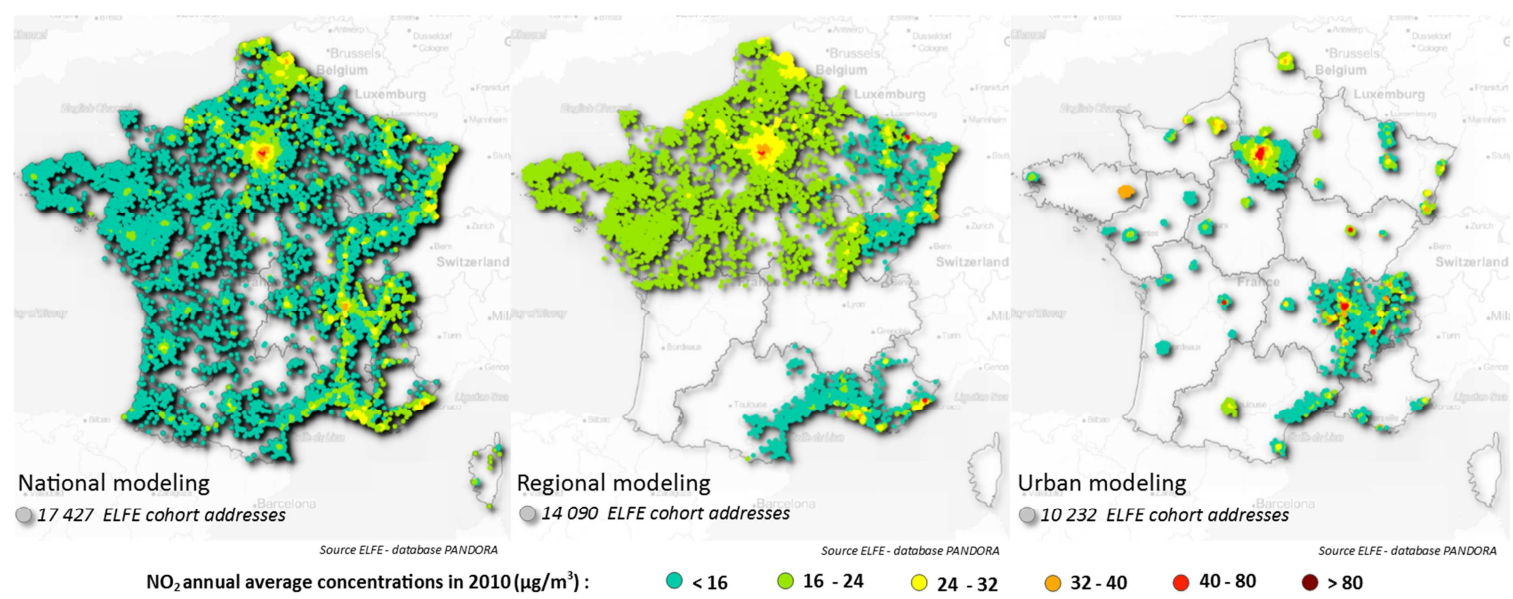

Figure 6: Annual averaged $\mathrm{NO}_{2}$ concentrations in 2010 for the addresses of the ELFE population where a national, regional or urban model existed. 


\begin{tabular}{|c|c|c|c|c|c|c|c|c|c|c|c|c|c|c|c|c|c|c|c|c|c|c|c|c|}
\hline \multirow{2}{*}{$\begin{array}{l}\text { Pollutant } \\
\text { Exposure } \\
\text { window }\end{array}$} & \multirow[b]{2}{*}{$\mathrm{n}$} & \multirow[b]{2}{*}{ mean } & \multicolumn{5}{|c|}{$\begin{array}{l}\text { National modeling } \\
\text { Percentiles }\end{array}$} & \multirow[b]{2}{*}{95} & \multicolumn{8}{|c|}{ Regional modeling } & \multicolumn{8}{|c|}{ Urban modeling } \\
\hline & & & sd & 5 & 25 & 50 & 75 & & $\mathrm{n}$ & $\begin{array}{c}\text { mea } \\
\mathrm{n}\end{array}$ & sd & 5 & 25 & 50 & 75 & 95 & $\mathrm{n}$ & mean & sd & 5 & 25 & 50 & 75 & 95 \\
\hline \multicolumn{25}{|l|}{$\overline{\mathrm{NO}_{2}}$} \\
\hline $\mathrm{P}$ & 15909 & 20.2 & 9.0 & 7.7 & 12.9 & 19.0 & 26.5 & 36.6 & 12571 & 22.9 & 8.3 & 9.4 & 17.5 & 21.9 & 28.2 & 38.3 & 8942 & 26.2 & 12.6 & 9.2 & 17.4 & 24.4 & 32.8 & 50.1 \\
\hline $\mathrm{T} 1$ & 15744 & 22.3 & 10.5 & 7.4 & 14.1 & 20.9 & 29.1 & 41.7 & 12467 & 25.1 & 9.3 & 9.9 & 18.9 & 24.5 & 31.5 & 41.6 & 8828 & 28.1 & 14.3 & 8.7 & 18.2 & 26.3 & 35.7 & 55.1 \\
\hline $\mathrm{T} 2$ & 16173 & 19.1 & 10.6 & 5.6 & 10.8 & 16.9 & 25.5 & 40.0 & 12773 & 21.8 & 10.0 & 6.8 & 14.3 & 21.0 & 28.7 & 40.7 & 9156 & 24.9 & 13.6 & 7.6 & 15.0 & 22.7 & 31.8 & 51.1 \\
\hline $\mathrm{T} 3$ & 16805 & 19.0 & 10.2 & 5.8 & 11.0 & 17.0 & 25.2 & 39.3 & 13263 & 21.6 & 9.5 & 7.0 & 15.0 & 20.1 & 27.9 & 39.8 & 9626 & 25.3 & 13.3 & 7.7 & 15.7 & 23.4 & 32.0 & 50.5 \\
\hline M5 & 16260 & 19.1 & 11.3 & 5.3 & 10.2 & 16.6 & 25.5 & 42.0 & 12847 & 21.6 & 10.5 & 6.5 & 13.6 & 20.0 & 28.9 & 41.3 & 9228 & 24.7 & 14.3 & 7.1 & 14.4 & 22.0 & 31.9 & 52.5 \\
\hline WBB3 & 17307 & 18.7 & 11.1 & 4.5 & 10.1 & 16.6 & 25.4 & 39.7 & 13667 & 21.0 & 10.4 & 5.3 & 13.0 & 20.0 & 27.8 & 39.6 & 9945 & 24.4 & 14.4 & 6.5 & 13.9 & 21.6 & 32.0 & 51.6 \\
\hline DBB & 17375 & 20.7 & 15.0 & 4.7 & 9.7 & 16.6 & 27.6 & 49.9 & 13720 & 23.7 & 14.6 & 5.6 & 14.0 & 20.5 & 30.1 & 52.3 & 10074 & 27.6 & 18.9 & 5.7 & 14.1 & 23.2 & 36.6 & 64.4 \\
\hline \multicolumn{25}{|l|}{$\mathrm{PM}_{2.5}$} \\
\hline $\mathrm{P}$ & 15909 & 17.2 & 2.9 & 12.7 & 15.2 & 16.9 & 19.0 & 22.6 & 12978 & 15.8 & 4.6 & 9.0 & 12.2 & 15.8 & 18.7 & 23.3 & 8281 & 16.2 & 3.9 & 9.4 & 140 & 16.3 & 18.7 & 22.0 \\
\hline $\mathrm{T} 1$ & 15744 & 18.9 & 5.6 & 10.9 & 14.6 & 18.1 & 22.4 & 29.2 & 12869 & 17.4 & 6.3 & 7.8 & 13.0 & 16.7 & 21.1 & 28.9 & 8298 & 18.0 & 5.9 & 9.5 & 13.9 & 17.6 & 21.7 & 28.3 \\
\hline $\mathrm{T} 2$ & 16173 & 16.5 & 6.5 & 8.9 & 11.4 & 14.5 & 20.8 & 29.2 & 13183 & 15.0 & 7.0 & 5.9 & 9.3 & 14.1 & 19.0 & 28.0 & 8526 & 15.7 & 6.8 & 7.2 & 10.2 & 14.1 & 20.4 & 27.9 \\
\hline $\mathrm{T} 3$ & 16805 & 16.1 & 5.8 & 9.5 & 12.0 & 14.5 & 19.2 & 28.0 & 13687 & 14.8 & 6.4 & 6.7 & 9.7 & 13.9 & 18.5 & 26.8 & 9017 & 15.3 & 6.2 & 7.3 & 10.6 & 14.2 & 18.9 & 27.1 \\
\hline M5 & 16260 & 17.0 & 8.4 & 8.7 & 10.3 & 13.6 & 22.6 & 33.5 & 13257 & 15.1 & 8.0 & 6.1 & 8.5 & 13.2 & 19.5 & 31.3 & 8567 & 16.0 & 8.3 & 7.1 & 9.5 & 13.0 & 21.9 & 32.2 \\
\hline WBB3 & 17307 & 16.4 & 9.9 & 6.7 & 8.3 & 11.8 & 23.0 & 35.2 & 14101 & 14.9 & 10.0 & 4.0 & 7.1 & 12.2 & 20.6 & 34.8 & 9399 & 15.0 & 8.9 & 5.6 & 7.8 & 11.6 & 21.4 & 31.9 \\
\hline DBB & 17375 & 15.3 & 7.0 & 6.5 & 10.1 & 14.2 & 19.4 & 28.4 & 14154 & 14.3 & 8.4 & 4.7 & 7.8 & 12.2 & 18.7 & 30.5 & 9571 & 14.9 & 7.7 & 5.1 & 8.8 & 13.6 & 19.4 & 28.8 \\
\hline \multicolumn{25}{|l|}{$\mathrm{PM}_{10}$} \\
\hline $\mathrm{P}$ & 15909 & 24.5 & 3.4 & 19.3 & 21.9 & 24.1 & 26.8 & 30.5 & 12978 & 25.1 & 3.3 & 19.8 & 22.7 & 25.1 & 27.3 & 30.4 & 8878 & 25.0 & 5.6 & 15.5 & 21.7 & 24.8 & 28.3 & 34.1 \\
\hline $\mathrm{T} 1$ & 15744 & 26.0 & 6.2 & 17.4 & 21.1 & 25.0 & 30.2 & 37.3 & 12869 & 26.6 & 6.0 & 17.3 & 21.9 & 26.2 & 30.9 & 37.2 & 8736 & 26.5 & 7.7 & 15.5 & 20.7 & 25.6 & 31.8 & 39.8 \\
\hline $\mathrm{T} 2$ & 16173 & 23.6 & 6.9 & 15.0 & 18.3 & 22.0 & 27.9 & 37.0 & 13183 & 24.2 & 6.7 & 15.2 & 18.7 & 23.1 & 28.5 & 37.1 & 9079 & 24.2 & 8.0 & 13.6 & 18.5 & 22.7 & 29.2 & 39.0 \\
\hline $\mathrm{T} 3$ & 16805 & 23.6 & 6.2 & 15.5 & 19.0 & 22.1 & 27.3 & 36.1 & 13687 & 24.2 & 6.1 & 15.8 & 19.7 & 23.2 & 27.9 & 36.3 & 9545 & 24.0 & 7.6 & 12.9 & 18.8 & 23.2 & 28.5 & 38.1 \\
\hline M5 & 16260 & 23.9 & 8.8 & 14.1 & 17.5 & 20.8 & 29.1 & 41.6 & 13257 & 24.4 & 8.3 & 14.8 & 18.4 & 21.4 & 29.5 & 40.9 & 9148 & 24.4 & 9.4 & 12.3 & 17.8 & 21.8 & 30.0 & 42.9 \\
\hline WBB3 & 17307 & 23.0 & 10.3 & 11.7 & 14.7 & 19.3 & 30.1 & 42.7 & 14101 & 23.5 & 10.2 & 12.5 & 15.0 & 19.5 & 31.3 & 42.6 & 9862 & 22.8 & 10.2 & 10.5 & 15.2 & 19.4 & 30.3 & 41.9 \\
\hline DBB & 17375 & 23.3 & 9.7 & 10.5 & 16.4 & 21.6 & 28.7 & 42.1 & 14154 & 23.7 & 10.3 & 10.2 & 16.6 & 21.2 & 29.4 & 43.8 & 9991 & 24.0 & 11.3 & 8.8 & 15.5 & 21.9 & 31.2 & 45.3 \\
\hline
\end{tabular}

Table 1: Averaged exposures during pregnancy as estimated for each of the 3 models 


\subsection{Confidence index of estimated exposures and comparison across the 3 models}

The confidence indexes were calculated for each address of the cohort, each pollutant and each year. The figure 7 presents the results of these calculations for $\mathrm{NO}_{2}$ in 2010 in the Strasbourg metropolitan area.

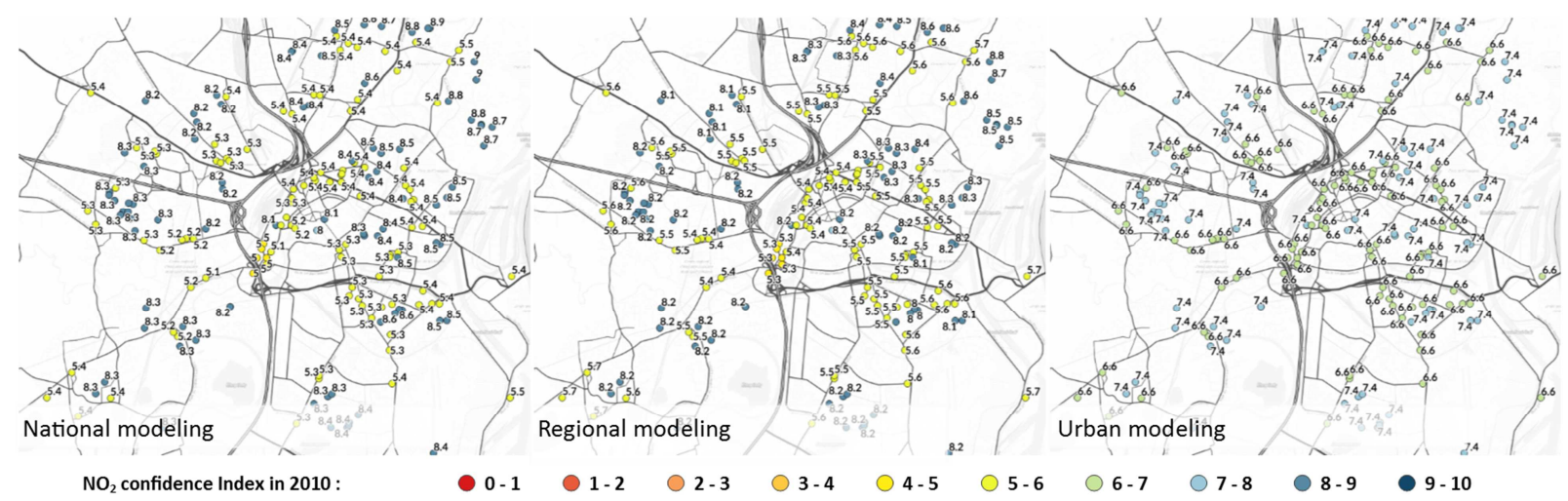

Figure 7: $\mathrm{NO}_{2}$ estimated confidence indexes for women of the ELFE cohort living in the Strasbourg agglomeration area in 2010

We compared the confidence indexes for women covered by the 3 models (Table 2). With the exception of $\mathrm{PM}_{2.5}$ and $\mathrm{NO}_{2}$ estimated by the regional models, the averaged confidence indexes were about 7.5 depending on the pollutant, year and exposure model considered (Table 2). For $\mathrm{NO}_{2}$ and $\mathrm{PM}_{2.5}$, the lowest $\mathrm{C}$ was observed for the regional modeling ( 0 for both pollutants) and the highest $\mathrm{C}$ was observed for the national modeling for $\mathrm{NO}_{2}(9.3)$ and for the urban modeling for $\mathrm{PM}_{2.5}$ (9.3). For $\mathrm{PM}_{10}$, the urban modeling showed the lowest (1.5) and highest $\mathrm{C}(10)$. Estimated confidence indexes were quite stable between 2010 and 2011. For $\mathrm{NO}_{2}$ confidence indexes, $10 \%$ of women had differences greater than 1 across the 3 models. For both $\mathrm{PM}_{2.5}$ and $\mathrm{PM}_{10}$ confidence indexes, $10 \%$ of women had differences greater than 1 for the national modeling compared to the regional modeling. As for the urban modeling, $30 \%$ of women for $\mathrm{PM}_{2.5}(20 \%$ for $\mathrm{PM}_{10}$ ) had differences in confidence indexes greater than 1 compared to the regional modeling. The PATer final exposure of the women was mostly estimated from the urban model for $\mathrm{NO}_{2}$ and $\mathrm{PM}_{10}$ and from the national model for $\mathrm{PM}_{2.5}$ (Figure 8). $\mathrm{PM}_{2.5}$ estimates from the regional model showed in average the lowest confidence indexes (Table 2) and the regional model was almost never chosen to represent the PATer final $\mathrm{PM}_{2.5}$ exposure estimate (Figure 8). 


\begin{tabular}{llllllllllllllll}
\hline Pollutant & Year & $\mathrm{n}$ & \multicolumn{4}{c}{ National modeling } & \multicolumn{4}{c}{ Regional modeling } & \multicolumn{3}{c}{ Urban modeling } \\
& & & & mean & sd & min & max & mean & sd & min & max & mean & sd & min & $\max$ \\
\hline $\mathrm{NO}_{2}$ & 2010 & 7817 & 7.2 & 1.9 & 3.0 & 9.2 & 6.9 & 2.0 & 0 & 9.2 & 7.2 & 0.9 & 4.2 & 8.8 \\
& 2011 & 7725 & 7.3 & 1.9 & 3.1 & 9.3 & 7.0 & 1.9 & 0 & 9.1 & 7.3 & 1.0 & 3.7 & 8.6 \\
$\mathrm{PM}_{2.5}$ & 2010 & $2330^{1}$ & 7.5 & 0.5 & 6.9 & 8.9 & 5.9 & 2.1 & 0 & 8.3 & 8.0 & 0.3 & 7.1 & 9.2 \\
& 2011 & $2503^{1}$ & 7.2 & 0.6 & 6.5 & 8.4 & 5.6 & 2.3 & 0 & 8.2 & 7.9 & 0.6 & 6.5 & 9.3 \\
$\mathrm{PM}_{10}$ & 2010 & 7402 & 7.7 & 1.1 & 5.1 & 9.1 & 7.4 & 1.0 & 5.1 & 9.1 & 7.6 & 1.1 & 3.9 & 10 \\
& 2011 & 7616 & 7.7 & 0.9 & 5.0 & 9.1 & 7.4 & 1.0 & 4.1 & 8.8 & 7.8 & 0.9 & 1.5 & 10 \\
\hline
\end{tabular}

$350{ }^{1}$ the number of observations is lower for $\mathrm{PM}_{2.5}$ compared to $\mathrm{PM}_{10}$ and $\mathrm{NO}_{2}$ because there were 351 fewer monitoring stations measuring $\mathrm{PM}_{2.5}$

Table 2: Averaged confidence index by pollutant, year and type of modeling for all women covered by the 3 models
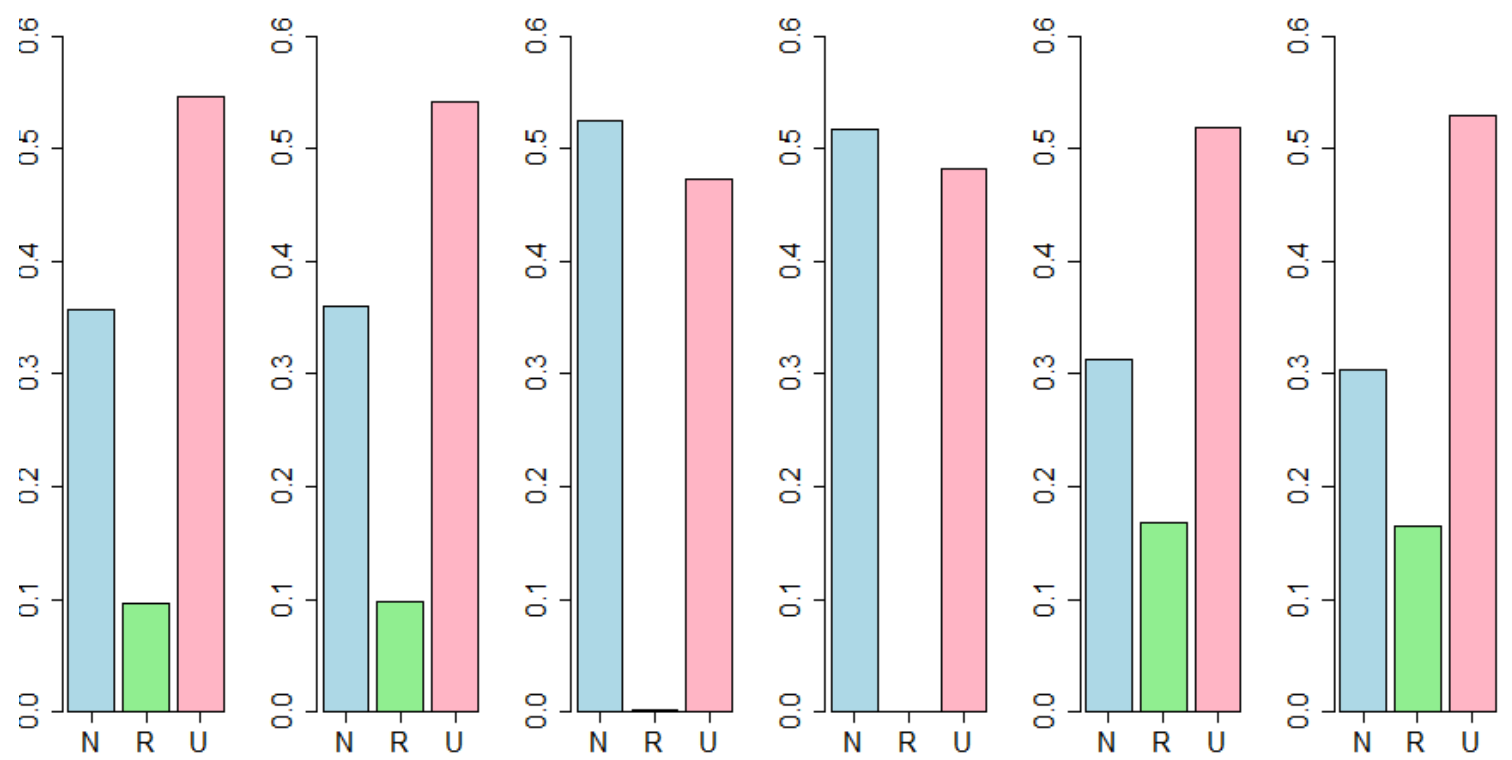

N: National model, R: Regional model, U: Urban model

Figure 8: Sources of the PATer final exposure estimate by pollutant and year. 
Depending on the exposure window, between 6,406 and 7,515 women were covered by the three exposure models and the final PATer estimates (Supplemental Table S1). Except $\mathrm{PM}_{2.5}$ correlation during the whole pregnancy between the national and regional models, the three models were highly correlated (correlation coefficients from 0.71 to 0.96 , Supplemental Table S2) for all pollutants and exposure windows. For the three pollutants, the exposure distributions of the urban model and the PATer estimates were very similar as shown by statistics in Supplemental Table S1 and by the very high correlation coefficients between exposures estimates from these 2 models (i.e. between 0.95 and 0.99, Supplemental Table S2); this result was expected because these statistics and correlation coefficients were calculated for women covered by the 3 models, which restricts the sample mainly to women living in urban areas, and the final PATer estimates gives priority to the urban model, which is therefore highly represented in this sub-sample.

$\mathrm{NO}_{2}$ exposures $\left(\mu \mathrm{g} / \mathrm{m}^{3}\right)$ as estimated by the national and regional models were very close $\left(\mathrm{p} 5^{\text {th }}\right.$, $50^{\text {th }}, 95^{\text {th }}$ during pregnancy $13,26,40$ and $13,27,40$, respectively), while the urban and PATer estimates showed a higher variability (larger standard deviation) and a wider distribution ( $\mathrm{p} 5^{\text {th }}$, $50^{\text {th }}, 95^{\text {th }}$ during pregnancy $11,25,50$ for both models) compared to the national and regional models (Figure 5 and Supplemental Table S1).

As for $\mathrm{PM}_{2.5}\left(\mu \mathrm{g} / \mathrm{m}^{3}\right)$, generally for the different time windows, the averages and standard deviations of exposures were slightly higher and the distributions were shifted to the right for the national model as compared to the regional, urban and PATer estimates. These results indicate that exposures from the national model were slightly higher $\left(\mathrm{p} 5^{\text {th }}, 50^{\text {th }}, 95^{\text {th }}\right.$ for pregnancy 14,18 , 23) than those from the regional, urban and PATer estimates $\left(\mathrm{p} 5^{\text {th }}, 50^{\text {th }}, 95^{\text {th }}\right.$ for pregnancy 10,17, 22 for the regional and 12, 17, 22 for the urban and PATer estimates).

For $\mathrm{PM}_{10}\left(\mu \mathrm{g} / \mathrm{m}^{3}\right)$, the exposure distribution of the women as estimated from the national and regional models were very close $\left(\mathrm{p} 5^{\text {th }}, 50^{\text {th }}, 95^{\text {th }}\right.$ for pregnancy $21,26,31$, and $22,26,31$ respectively). As compared to the national and regional models, the urban model and PATer estimates showed slightly higher standard deviations and medians as well as slightly wider distributions for the different time windows investigated ( $\mathrm{p} 5^{\text {th }}, 50^{\text {th }}, 95^{\text {th }}$ for pregnancy $20,26,35$ for both models).

Altogether, the urban and PATer estimates were finer and better captured the spatial variability compared to the national and regional models, especially for $\mathrm{NO}_{2}$ and $\mathrm{PM}_{10}$. As expected, for the 
404

3 pollutants and the 4 models, larger distribution of exposure was observed for shorter exposure time windows compared to longer time windows.

\subsection{Pregnancy exposures as estimated by the final PATer most suitable estimate}

Exposures of the women as estimated by the urban model when there is one available or by the model with the highest confidence index from the regional and national models are described in table 3. In average during pregnancy, women were exposed to $21 \mu \mathrm{g} / \mathrm{m}^{3}$ for $\mathrm{NO}_{2}, 16 \mu \mathrm{g} / \mathrm{m}^{3}$ for $\mathrm{PM}_{2.5}$ and $24 \mu \mathrm{g} / \mathrm{m}^{3}$ for $\mathrm{PM}_{10}$. As shown in table 3, 90\% of the estimated exposures had a confidence index comprised between 5.2 and 8.7 for $\mathrm{NO}_{2}, 6.8$ and 9.0 for $\mathrm{PM}_{2.5}$, and 6.1 and 8.6 for $\mathrm{PM}_{10}$.

\begin{tabular}{|c|c|c|c|c|c|c|c|c|c|}
\hline \multirow[t]{2}{*}{ Pollutant } & \multirow[t]{2}{*}{ Exposure window } & \multirow[t]{2}{*}{$\mathrm{n}$} & \multirow[t]{2}{*}{ mean } & \multirow[t]{2}{*}{$\mathrm{sd}$} & \multicolumn{5}{|c|}{ percentile } \\
\hline & & & & & 5 & 25 & 50 & 75 & 95 \\
\hline \multirow[t]{8}{*}{$\mathrm{NO}_{2}$} & Confidence index & 17188 & 7.5 & 1.1 & 5.2 & 6.7 & 8.1 & 8.4 & 8.7 \\
\hline & Pregnancy & 17188 & 20.9 & 11.8 & 6.9 & 12.2 & 18.5 & 26.5 & 44.0 \\
\hline & $\mathrm{T} 1$ & 15971 & 22.8 & 13.1 & 6.7 & 13.4 & 20.4 & 29.2 & 48.2 \\
\hline & $\mathrm{T} 2$ & 16445 & 19.9 & 12.7 & 5.2 & 10.6 & 17.0 & 26.2 & 44.1 \\
\hline & $\mathrm{T} 3$ & 16675 & 20.0 & 12.6 & 5.5 & 10.9 & 17.2 & 26.0 & 43.9 \\
\hline & M5 & 16104 & 19.9 & 13.1 & 5.0 & 10.2 & 16.8 & 26.3 & 44.9 \\
\hline & WBB3 & 16741 & 19.7 & 13.4 & 4.3 & 9.9 & 16.7 & 26.4 & 44.9 \\
\hline & DBB & 16793 & 21.7 & 17.1 & 4.3 & 9.7 & 17.1 & 28.4 & 55.5 \\
\hline \multirow[t]{8}{*}{$\mathrm{PM}_{2.5}$} & Confidence index & 17203 & 7.9 & 0.7 & 6.8 & 7.5 & 7.8 & 8.3 & 9.0 \\
\hline & Pregnancy & 17203 & 16.2 & 3.7 & 10.4 & 14.0 & 16.1 & 18.5 & 22.3 \\
\hline & $\mathrm{T} 1$ & 16005 & 18.0 & 5.6 & 10.2 & 13.9 & 17.5 & 21.6 & 27.9 \\
\hline & $\mathrm{T} 2$ & 16469 & 15.6 & 6.3 & 8.0 & 10.5 & 14.0 & 19.9 & 27.3 \\
\hline & $\mathrm{T} 3$ & 16683 & 15.2 & 5.6 & 8.4 & 11.1 & 13.9 & 18.3 & 26.5 \\
\hline & M5 & 16124 & 16.0 & 7.9 & 7.9 & 9.9 & 13.1 & 21.1 & 31.6 \\
\hline & WBB3 & 16749 & 15.3 & 9.3 & 6.1 & 7.9 & 11.2 & 21.4 & 32.9 \\
\hline & DBB & 16658 & 14.7 & 6.9 & 5.5 & 9.3 & 13.7 & 18.8 & 27.3 \\
\hline \multirow[t]{8}{*}{$\mathrm{PM}_{10}$} & Confidence index & 17195 & 7.7 & 0.8 & 6.1 & 7.1 & 7.8 & 8.4 & 8.6 \\
\hline & Pregnancy & 17195 & 23.8 & 4.9 & 16.7 & 20.9 & 23.4 & 26.7 & 32.0 \\
\hline & $\mathrm{T} 1$ & 15980 & 25.6 & 6.9 & 16.1 & 20.5 & 24.7 & 30.1 & 37.9 \\
\hline & $\mathrm{T} 2$ & 16456 & 23.2 & 7.2 & 14.2 & 17.8 & 21.6 & 27.7 & 37.1 \\
\hline & $\mathrm{T} 3$ & 16682 & 23.0 & 6.8 & 14.2 & 18.5 & 21.7 & 27.0 & 36.2 \\
\hline & M5 & 16114 & 23.4 & 8.7 & 13.2 & 17.3 & 20.6 & 28.6 & 41.0 \\
\hline & WBB3 & 16748 & 22.1 & 9.6 & 11.1 & 14.6 & 18.8 & 28.9 & 40.3 \\
\hline & DBB & 16814 & 23.0 & 10.1 & 9.5 & 15.7 & 21.3 & 28.7 & 42.8 \\
\hline
\end{tabular}


T1: trimester 1, T2: trimester 2, T3: trimester 3, M5: month 5, WBB3: $3^{\text {rd }}$ week before birth , DBB: day before birth

Table 3 : Averaged exposures and confidence indexes during pregnancy as estimated by the most suitable model for pregnant women of the ELFE cohort

\section{Discussion}

To our knowledge, this is the first study combining three modeling tools available at different scales to estimate $\mathrm{NO}_{2}, \mathrm{PM}_{10}$ and $\mathrm{PM}_{2.5}$ concentrations at a fine spatial (down to 10 meters) and temporal (hourly) resolution over a large geographical area (the French metropolitan area). We further estimated a confidence index based on the target plot and Model Quality Indicator in order to provide guidance in the choice of the exposure model, when several models are available. Our results showed that the three models provided relatively similar exposure estimates for the women of the ELFE cohort, allowing a combination of the three models. The urban-scale model provides a finer spatial resolution compared to the national and regional models, which is relevant in urban and peri-urban areas that are more densely populated and where local emissions mainly originate from traffic and heating processes. We therefore chose to favor the urban-scale model first, and to then use the confidence index to choose between the regional- and nationalscale models for women who were not covered by the urban-scale model. We finally used the predicted concentrations of these models to evaluate the exposure during multiple time-windows of 17,427 pregnant women participating to the ELFE cohort.

Two main modeling tools were used for the urban-scale model: ADMS Urban (Carruthers et al., 2000a) and SIRANE (Soulhac et al., 2017; 2011; 2012a). ADMS Urban accounts for linear sources such as traffic, but also for many stationary sources like industrial or residential sources. It also includes an intelligent gridding option, which provides high spatial resolution in the vicinity of air pollution sources such as roads. SIRANE cannot include as many stationary sources as ADMS-urban and its spatial resolution is identical throughout the simulated geographical area. However, SIRANE works on a very high spatial resolution throughout the Rhône-Alpes region, which therefore benefits from a very fine assessment of concentrations, including in the interurban environment. 
At the regional scale, a special feature of the modeling is the harmonized procedure used by all regional platforms. This common approach included accounting for sharp specificities within regions by using regional emission inventories (i.e. integration of spatialized and temporalized local data) that are more precise compared to the national emission inventories; the use of models in their configuration used in routine daily forecasting (CHIMERE, SIRANE, WRF or MM5) at 4 $\mathrm{x} 4 \mathrm{~km}$ or $3 \times 3 \mathrm{~km}$ resolution and then refined at $1 \times 1 \mathrm{~km}$ resolution; the application of a daily or hourly kriging of the measurements over the whole 2010 and 2011 (rather than a yearly kriging). These improvements led to better representation of local processes that influence ambient pollutants concentrations. Comparing the confidence indexes between the national model and the regional models requires some considerations: the national model integrates unified input data as weather or emissions and operates a single configuration of model throughout the national territory. Similarly, geostatic post-treatments are applied according to the same methodology overall of this same territory. The regional model consists in an agglomeration of results from several regional platforms. Each of these platforms delivers representative and coherent results within its regional coverage, by managing its own modeling based on its knowledge and experience on the models used, emissions and meteorological datasets used for modeling, regional modeling calibration, local specificities, etc. The heterogeneity of the platforms used to fuel the regional scale modeling can explain, at least partly, the overall poor performances and lower confidence indexes of the regional model compared to the national (and urban) model, with some regional models performing better than others.

The three models, national, regional and urban showed consistent distributions of exposure estimates. The national and regional models were very close in terms of exposure estimates. The urban models have a higher spatial resolution and showed a higher variability with a wider range of exposure estimates, which is consistent with the stronger exposure contrasts observed in urban and peri-urban areas compared to more rural areas. Further, the implementation of dedicated validation methods such as the Delta tool, the target plot, the model quality indicator and the confidence index substantiates the use of several exposure models. We showed that for the ELFE cohort, the exposure estimates from the three models were close enough to be combined in order to estimate air pollution exposure in this nation-wide population. The distributions of exposure to the different air pollutants were very close across the three models and highly correlated. The 
variability of the exposures was increased for predictions of the urban models compared to those of the national and regional models; however, this is relevant as it reflects a real situation where exposures are more contrasted in urban and peri-urban areas that are more densely populated and where emissions due to traffic and heating are higher than in other areas. Since the ELFE cohort is a representative sample of the French pregnant women, there is a priori no reason for the combination of the three models to not be relevant for any other study. However, this would need some validation by comparing the distribution of exposure estimate from the three models. In ELFE, with the exception of $\mathrm{NO}_{2}$, pregnancy exposure estimates were higher than air quality values recommended by the WHO, respectively 40, 10 and $20 \mu \mathrm{g} / \mathrm{m}^{3}$ in annual average for $\mathrm{NO}_{2}$, $\mathrm{PM}_{2.5}$ and $\mathrm{PM}_{10}$. In France, the limit values (according to the environmental code Article R221-1 Modified by the decree $\mathrm{n}^{\circ} 2010-1250$ of October 21st, 2010-art.1) are 40, 25 and $40 \mu \mathrm{g} / \mathrm{m}^{3}$ respectively for $\mathrm{NO}_{2}, \mathrm{PM}_{2.5}$ and $\mathrm{PM}_{10}\left(\mathrm{PM}_{2.5}\right.$ only from 2015) in annual averages.

A previous national model for France developed for the GAZEL cohort, used the European Monitoring and Evaluation Program (EMEP) emissions at a 50 x $50 \mathrm{~km}$ resolution and focused on a $10 \times 10 \mathrm{~km}$ CHIMERE grid with further improvements from specific recalculated data for traffic and main industrial sources. After simulation, the exposure data were then refined to a $2 \mathrm{x}$ $2 \mathrm{~km}$ resolution (Bentayeb et al., 2015). The "Pater model" represents a major improvement compared to this previous approach. However, we acknowledge some limits of our approach. One relates to the heterogeneity in the quality of predicted concentrations of the regional platforms (see above), which decreases the overall performances of the regional scale model. There was a restricted number (106) of $\mathrm{PM}_{2.5}$ monitors, which limited our ability to evaluate the performances of the three models using the target plot and corresponding MQI and C. The "Pater model" focus on years 2010 and 2011 in order to fit with the pregnancies of the women included in the ELFE cohort; this work needs to be expanded in order to estimate exposure of the ELFE children or to be used in other epidemiological studies that would have been conducted after 2011. The air pollutants exposure estimated for the women do not take into account the time spent by pregnant women inside the buildings (housing, workplace) or during commuting. A previous study performed in Grenoble, France, compared the exposure levels calculated from a dispersion model with those accounting for indoor and commuting sources (Ouidir et al., 2015). For $\mathrm{NO}_{2}$ and $\mathrm{PM}_{2.5}$, exposure assessed from a personal air sampler was poorly correlated with 
exposure estimated from a model based on outdoor concentrations, suggesting that outdoor levels do not reflect personal exposure. However, this result was based on a very small population $(n=9)$ and did not investigate the impact of measurement error on the association with the health outcome.

\section{Conclusion}

This work is an important step towards the harmonization and combination of the different air quality modeling tools used at different scales in France in order to promote a consistent approach throughout the national territory. In the ELFE cohort, prenatal exposures to air pollutants will be used to investigate their potential effects on the pregnant woman health, on the fetal health, and on the child's neurodevelopment and respiratory health. In a broader perspective, data from the PATer database can be used for other epidemiological studies as well as for health impact studies. The next step of this project is to maintain and update the database for year 2012 and following years in order to estimate postnatal exposures to air pollutants for children of the ELFE cohort and to allow more epidemiological studies conducted in 2010 and after to use these exposure data.

\section{Acknowledgment}

We thank the members of the PATer (Pollution Atmosphérique sur le territoire français) project steering committee: Alina Holcroft (ATMO France); Emmanuel Rivière, Julien Bernard (ATMO Grand Est); Johanna Lepeule, Emie Seyve, Rémy Slama (INSERM); Jérôme Cortinovis, Véronique Delmas (ATMO Normandie); Pierre-Yves Robic, Dominique Tilak (ATMO Occitanie); Fabrice Dugay, Olivier Sanchez (AIRPARIF); François Ducroz, Arnaud Rebours (AIR Pays-de-la-Loire); Agnès Hulin, Alain Gazeau (ATMO Nouvelle Aquitaine); Laure Malherbe, Elsa Real, Augustin Colette, Anthony Ung (INERIS); Xavier Villetard, Jonathan Virga (AIR PACA); Mathilde Pascal, Malek Bentayeb (Santé Publique France).

We also express our gratitude to all the other metropolitan AASQAs who gave their time and expertise for the realization of this project: ATMO Hauts-de-France, AIR Breitzh, ATMO Auvergne-Rhône-Alpes, ATMO Bourgogne-Franche-Comté, Lig’Air, Qualit'Air Corse.

We thank the volunteers participating in the ELFE cohort. ELFE is a study conducted jointly by the National Institute of Demographic Studies (Ined), the French National Institute for Health and 
Medical Research (Inserm), French blood establishment (EFS), French Institute for Public Health Surveillance (InVS), French National Institute for Statistics and Economic Studies (Insee), General Directorate for Health (DGS, Ministry of Health), General Directorate for Risk Prevention (DGPR, Ministry of Environment), Directorate for Research, Studies, Evaluation and Statistics (Drees), and the French National Family Allowance Fund (Cnaf). It benefits from additional funding from the Ministry of Research, Committee on SHS data (CCDSHS) and Ministry of Culture and Communication (Deps) Ministry of Culture and Communication. As part of the RECONAI platform, ELFE benefits from ANR funding (ANR-11-EQPX-0038). The production of national maps received support from the research project SysCLAD.

\section{Funding}

This work was supported by ANSES (the French Agency for Food, Environmental and Occupational Health \& Safety; Grant No EST 2013-1-216) in the context of the PATer (Pollution Atmosphérique sur le territoire français) project.

\section{Références}

Beauchamp, M., 2014. Estimation des populations exposées aux dépassements de seuils réglementaires 1. Echelle urbaine. Retrieved December 5, 2018, from https://www.lcsqa.org/system/files/lcsqa2014-rapport_estimationpopulation_exposees_depassements-echelle_urbaine-drc-16-152374-00051a.pdf

Benmerad, M., Slama, R., Botturi, K., Claustre, J., Roux, A., Sage, E., Reynaud-Gaubert, M., Gomez, C., Kessler, R., Brugière, O., Mornex, J.-F., Mussot, S., Dahan, M., Boussaud, V., Danner-Boucher, I., Dromer, C., Knoop, C., Auffray, A., Lepeule, J., Malherbe, L., Meleux, F., Nicod, L., Magnan, A., Pison, C., Siroux, V., SysCLAD consortium, 2017. Chronic effects of air pollution on lung function after lung transplantation in the Systems prediction of Chronic Lung Allograft Dysfunction (SysCLAD) study. European Respiratory Journal 49. doi:10.1183/13993003.00206-2016

Bentayeb, M., Wagner, V., Stempfelet, M., Zins, M., Goldberg, M., Pascal, M., Larrieu, S., Beaudeau, P., Cassadou, S., Eilstein, D., Filleul, L., Le Tertre, A., Medina, S., Pascal, L., Prouvost, H., Quénel, P., Zeghnoun, A., Lefranc, A., 2015. Association between long-term exposure to air pollution and mortality in France: A 25-year follow-up study. Environ Int 85, 5-14. doi:10.1016/j.envint.2015.08.006

Carruthers, D.J., Edmunds, H.A., Lester, A.E., McHugh, C.A., Singles, R.J., 2000a. Use and validation of ADMS-Urban in contrasting urban and industrial locations. International Journal of Environment and Pollution 14, 364. doi:10.1504/IJEP.2000.000558

Carruthers, D.J., Edmunds, H.A., Lester, A.E., McHugh, C.A., Singles, R.J., 2000b. Use and validation of ADMS-Urban in contrasting urban and industrial locations. International Journal of Environment and Pollution 14, 364. doi:10.1504/IJEP.2000.000558

Clifford, A., Lang, L., Chen, R., Anstey, K.J., Seaton, A., 2016. Exposure to air pollution and 
cognitive functioning across the life course - A systematic literature review. Environ. Res. 147, 383-398. doi:10.1016/j.envres.2016.01.018

Eeftens, M., Beelen, R., de Hoogh, K., Bellander, T., Cesaroni, G., Cirach, M., Declercq, C., Dedele, A., Dons, E., de Nazelle, A., Dimakopoulou, K., Eriksen, K., Falq, G., Fischer, P., Galassi, C., Grazuleviciene, R., Heinrich, J., Hoffmann, B., Jerrett, M., Keidel, D., Korek, M., Lanki, T., Lindley, S., Madsen, C., Mölter, A., Nádor, G., Nieuwenhuijsen, M., Nonnemacher, M., Pedeli, X., Raaschou-Nielsen, O., Patelarou, E., Quass, U., Ranzi, A., Schindler, C., Stempfelet, M., Stephanou, E., Sugiri, D., Tsai, M.-Y., Yli-Tuomi, T., Varró, M.J., Vienneau, D., Klot, S.V., Wolf, K., Brunekreef, B., Hoek, G., 2012. Development of Land Use Regression models for PM(2.5), PM(2.5) absorbance, PM(10) and PM(coarse) in 20 European study areas; results of the ESCAPE project. Environ. Sci. Technol. 46, 1119511205. doi:10.1021/es301948k

Honoré, C., Rouil, L., Vautard, R., Beekmann, M., Bessagnet, B., Dufour, A., Elichegaray, C., Flaud, J.-M., Malherbe, L., Meleux, F., Menut, L., Martin, D., Peuch, A., Peuch, V.-H., Poisson, N., 2008. Predictability of European air quality: Assessment of 3 years of operational forecasts and analyses by the PREV'AIR system. Journal of Geophysical Research 113, 2061. doi:10.1029/2007JD008761

Korten, I., Ramsey, K., Latzin, P., 2017. Air pollution during pregnancy and lung development in the child. Paediatr Respir Rev 21, 38-46. doi:10.1016/j.prrv.2016.08.008

Lavigne, E., Ashley-Martin, J., Dodds, L., Arbuckle, T.E., Hystad, P., Johnson, M., Crouse, D.L., Ettinger, A.S., Shapiro, G.D., Fisher, M., Morisset, A.-S., Taback, S., Bouchard, M.F., Sun, L., Monnier, P., Dallaire, R., Fraser, W.D., 2016. Air Pollution Exposure During Pregnancy and Fetal Markers of Metabolic function: The MIREC Study. Am J Epidemiol 183, 842-851. doi:10.1093/aje/kwv256

Mailler, S., Menut, L., Khvorostyanov, D., Valari, M., Couvidat, F., Siour, G., Turquety, S., Briant, R., Tuccella, P., Bessagnet, B., Colette, A., Létinois, L., Markakis, K., Meleux, F., 2017. CHIMERE-2017: from urban to hemispheric chemistry-transport modeling. Geosci. Model Dev. 10, 2397-2423. doi:10.5194/gmd-10-2397-2017

Malherbe, L., 2009. Travaux relatifs à la plate-forme nationale de modélisation PREV'AIR : Réalisation de cartes analysées d'ozone (2/2). Laboratoire central de surveillance de la qualité de l'air. Retrieved December 5, 2018, from https://www.lcsqa.org/fr/node/1603/printable/pdf

Malherbe, L., Wroblewski, A., Létinois, L., Rouil, L., 2010. Evaluation of numerical models used to simulate atmospheric pollution near roadways. hal-ineris.archives-ouvertes.fr 697-700.

Menut, L., Bessagnet, B., Khvorostyanov, D., Beekmann, M., Blond, N., Colette, A., Coll, I., Curci, G., Foret, G., Hodzic, A., Mailler, S., Meleux, F., Monge, J.L., Pison, I., Siour, G., Turquety, S., Valari, M., Vautard, R., Vivanco, M.G., 2013. CHIMERE 2013: a model for regional atmospheric composition modelling. Geosci. Model Dev. 6, 981-1028. doi:10.5194/gmd-6-981-2013

Oliveri Conti, G., Heibati, B., Kloog, I., Fiore, M., Ferrante, M., 2017. A review of AirQ Models and their applications for forecasting the air pollution health outcomes. Environ Sci Pollut Res Int 24, 6426-6445. doi:10.1007/s11356-016-8180-1

Ouidir, M., Giorgis-Allemand, L., Lyon-Caen, S., Morelli, X., Cracowski, C., Pontet, S., Pin, I., Lepeule, J., Siroux, V., Slama, R., 2015. Estimation of exposure to atmospheric pollutants during pregnancy integrating space-time activity and indoor air levels: Does it make a difference? Environ Int 84, 161-173. doi:10.1016/j.envint.2015.07.021 
Pedersen, M., Giorgis-Allemand, L., Bernard, C., Aguilera, I., Andersen, A.-M.N., Ballester, F., Beelen, R.M.J., Chatzi, L., Cirach, M., Danileviciute, A., Dedele, A., Eijsden, M.V., Estarlich, M., Fernández-Somoano, A., Fernández, M.F., Forastiere, F., Gehring, U., Grazuleviciene, R., Gruzieva, O., Heude, B., Hoek, G., de Hoogh, K., van den Hooven, E.H., Håberg, S.E., Jaddoe, V.W.V., Klümper, C., Korek, M., Krämer, U., Lerchundi, A., Lepeule, J., Nafstad, P., Nystad, W., Patelarou, E., Porta, D., Postma, D., Raaschou-Nielsen, O., Rudnai, P., Sunyer, J., Stephanou, E., Sørensen, M., Thiering, E., Tuffnell, D., Varró, M.J., Vrijkotte, T.G.M., Wijga, A., Wilhelm, M., Wright, J., Nieuwenhuijsen, M.J., Pershagen, G., Brunekreef, B., Kogevinas, M., Slama, R., 2013. Ambient air pollution and low birthweight: a European cohort study (ESCAPE). Lancet Respir Med 1, 695-704. doi:10.1016/S22132600(13)70192-9

Pedersen, M., Stayner, L., Slama, R., Sørensen, M., Figueras, F., Nieuwenhuijsen, M.J., Raaschou-Nielsen, O., Dadvand, P., 2014. Ambient air pollution and pregnancy-induced hypertensive disorders: a systematic review and meta-analysis. Hypertension 64, 494-500. doi:10.1161/HYPERTENSIONAHA.114.03545

Pernigotti, D., Gerboles, M., Belis, C.A., Thunis, P., 2013. Model quality objectives based on measurement uncertainty. Part II: NO2 and PM10. Atmospheric Environment 79, 869-878. doi:10.1016/j.atmosenv.2013.07.045

Pôle national de coordination des inventaires territoriaux, 2012. Guide méthodologique pour l'élaboration des inventaires territoriaux des émissions atmosphériques 1-293.

Sellier, Y., Galineau, J., Hulin, A., Caïni, F., Marquis, N., Navel, V., Bottagisi, S., GiorgisAllemand, L., Jacquier, C., Slama, R., Lepeule, J., EDEN Mother-Child Cohort Study Group, 2014. Health effects of ambient air pollution: do different methods for estimating exposure lead to different results? Environ Int 66, 165-173. doi:10.1016/j.envint.2014.02.001

Shah, P.S., Balkhair, T., Knowledge Synthesis Group on Determinants of Preterm/LBW births, 2011. Air pollution and birth outcomes: a systematic review. Environ Int 37, 498-516. doi:10.1016/j.envint.2010.10.009

Soulhac, L., Nguyen, C.V., Volta, P., Salizzoni, P., 2017. The model SIRANE for atmospheric urban pollutant dispersion. PART III: Validation against NO 2 yearly concentration measurements in a large urban agglomeration. Atmospheric Environment 167, 377-388. doi:10.1016/j.atmosenv.2017.08.034

Soulhac, L., Pietro Salizzoni, Cierco, F.X., Perkins, R., 2011. Atmospheric Environment. Atmospheric Environment 45, 7379-7395. doi:10.1016/j.atmosenv.2011.07.008

Soulhac, L., Salizzoni, P., Mejean, P., Didier, D., 2012a. The model SIRANE for atmospheric urban pollutant dispersion; PART II, validation of the model on a real case study. Atmospheric Environment.

Soulhac, L., Salizzoni, P., Mejean, P., Didier, D., Rios, I., 2012b. Atmospheric Environment. Atmospheric Environment 49, 320-337. doi:10.1016/j.atmosenv.2011.11.031

Stocker, J., Hood, C., Carruthers, D., McHugh, C., 2012. ADMS-Urban: developments in modelling dispersion from the city scale to the local scale. International Journal of Environment and Pollution 50, 308. doi:10.1504/IJEP.2012.051202

Thunis, P., Cuvelier, C., 2016. DELTA Version 5.2. Concepts / User's Guide / Diagrams. Ispra Joint Research Centre JRC 1-67.

Thunis, P., Pederzoli, A., Pernigotti, D., 2012. Performance criteria to evaluate air quality modeling applications. Atmospheric Environment 59, 476-482. doi:10.1016/j.atmosenv.2012.05.043

Thunis, P., Pernigotti, D., Gerboles, M., 2013. Model quality objectives based on measurement 
uncertainty. Part I: Ozone. Atmospheric Environment 79, 861-868. doi:10.1016/j.atmosenv.2013.05.018

Tognet, F., 2016. Etude comparative des modèles ADMS Urban et SIRANE sur un cas test. Laboratoire central de surveillance de la qualité de l'air. Retrieved December 5, 2018, from https://www.lcsqa.org/system/files/lcsqa2015-intercomparaison adms sirane drc-16152376-12019a_0.pdf.

Valari, M., Menut, L., Chatignoux, E., 2011. Using a chemistry transport model to account for the spatial variability of exposure concentrations in epidemiologic air pollution studies. J Air Waste Manag Assoc 61, 164-179.

Vandentorren, S., Bois, C., Pirus, C., Sarter, H., Salines, G., Leridon, H., Elfe team, 2009. Rationales, design and recruitment for the Elfe longitudinal study. BMC Pediatr 9, 58. doi:10.1186/1471-2431-9-58

Wroblewski, A., Létinois, L., Malherbe, L., 2009. Evaluation de modèles pour la simulation de la pollution à proximité des axes routiers. Laboratoire central de surveillance de la qualité de l'air. Retrieved December 5, 2018, from https://www.lcsqa.org/system/files/rapport/drc-10103347-01136_proximite_vf.pdf.

Xu, X., Ha, S.U., Basnet, R., 2016. A Review of Epidemiological Research on Adverse Neurological Effects of Exposure to Ambient Air Pollution. Front Public Health 4, 157. doi:10.3389/fpubh.2016.00157 


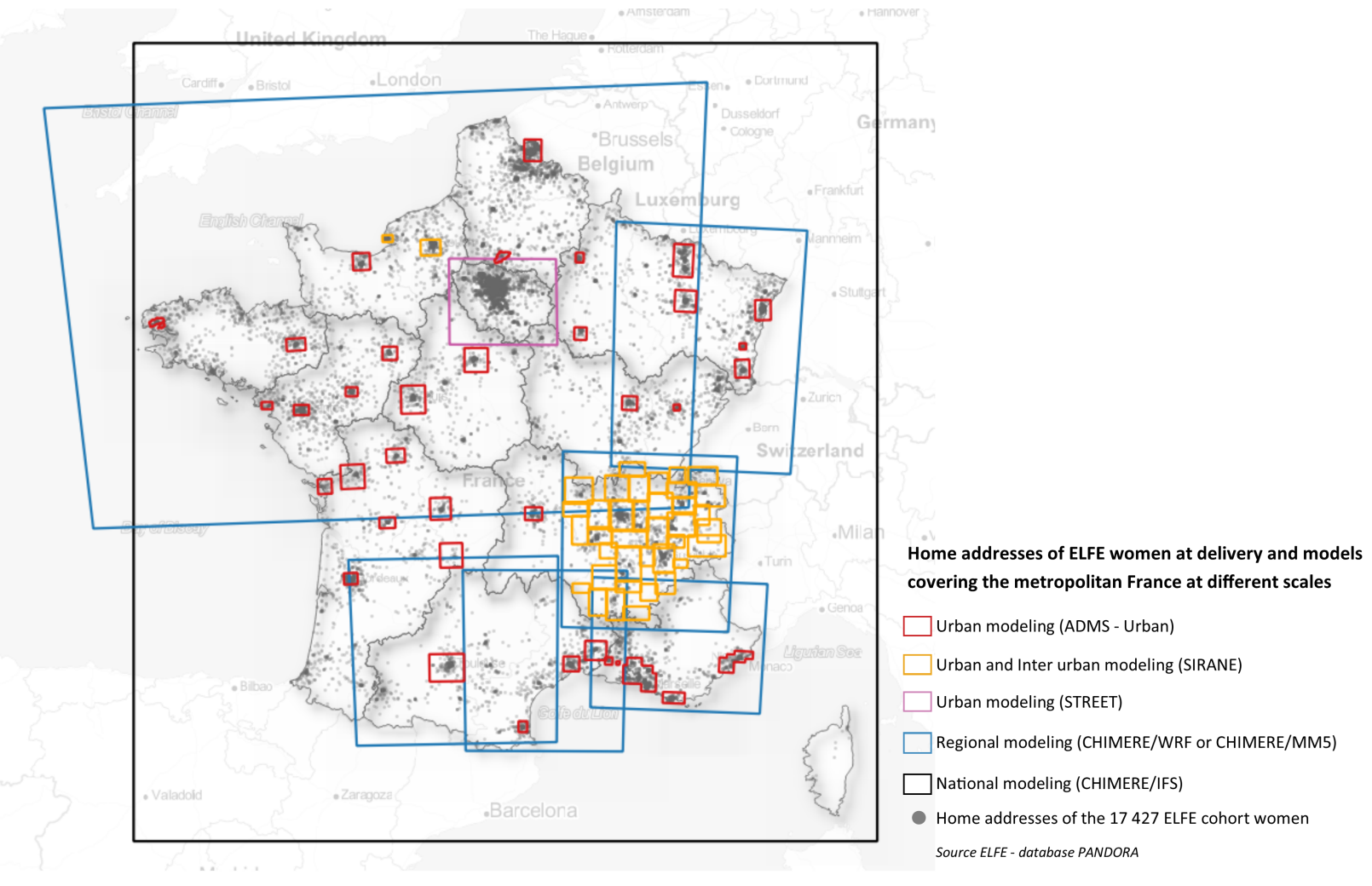




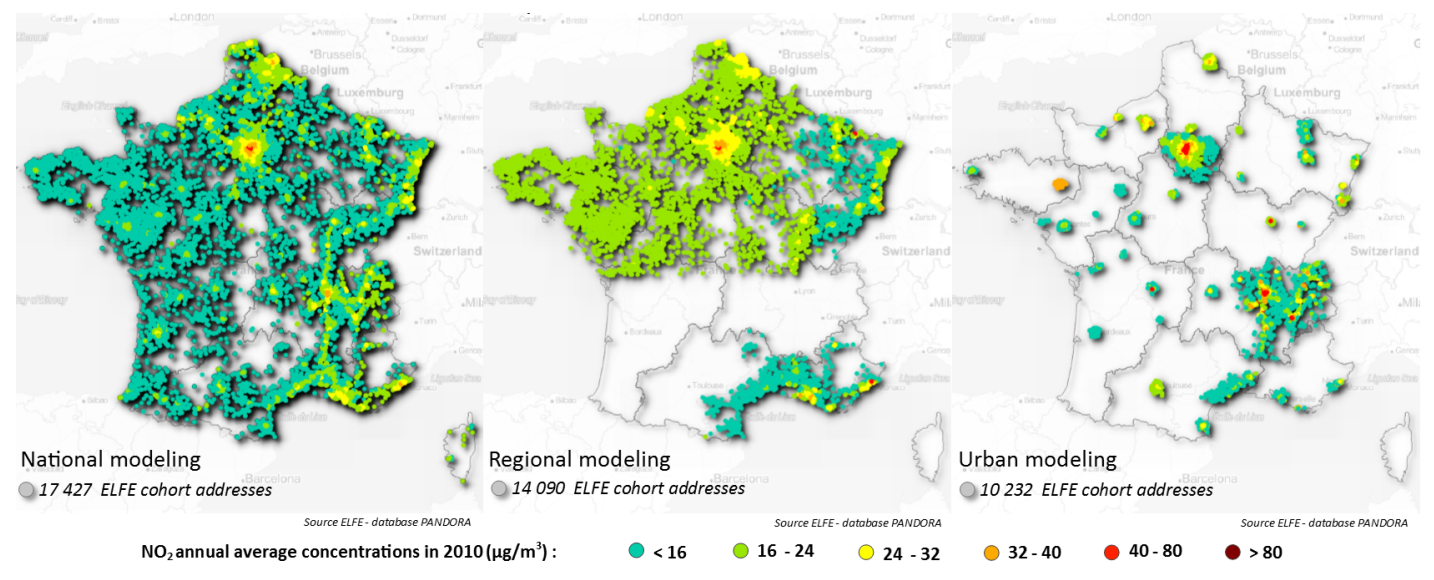




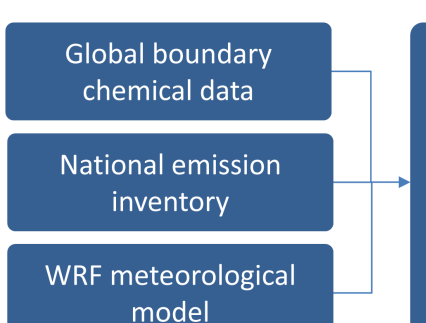

1

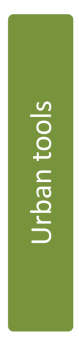

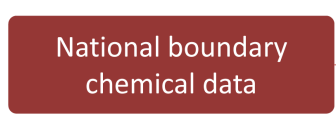

Regional emission

inventory

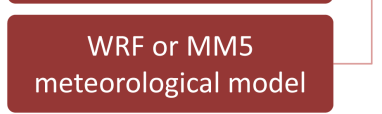

\section{Regional boundary} chemical data

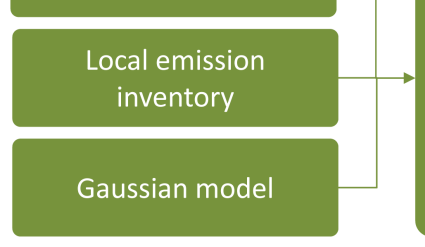

$\mathrm{NO}_{2}, \mathrm{PM}_{10} \mathrm{PM}_{2,5}$

Hourly concentrations

Post-treatment: to reach

$1 \mathrm{~km} \times 1 \mathrm{~km}$ resolution

\section{ESMERALDA, AIRES, \\ PREVEST, CHIMERE \\ Midi-Pyrénées \\ $\mathrm{NO}_{2,}, \mathrm{PM}_{10} \mathrm{PM}_{2,5}$ \\ Hourly concentrations \\ Post-treatment: to reach \\ $1 \mathrm{~km} \times 1 \mathrm{~km}$ resolution}

ADMS Urban, SIRANE

Run1 : $\mathrm{NO}_{2}, \mathrm{PM}_{10}, \mathrm{PM}_{2,5}$

At each address with

hourly concentrations

Run2 : $\mathrm{NO}_{2}, \mathrm{PM}_{10}, \mathrm{PM}_{25}$

Gridded with high

resolution $(10-200 m)$ and

annual concentrations
EXPOSURE : Daily concentrations data

at each address for each pollutant and each available model

EXPOSURE : Annual concentrations data

with high resolution

$(10 \mathrm{~m}$ to $1 \mathrm{~km})$ for each

pollutant and each

available model

Confidence index

for each concentration data 

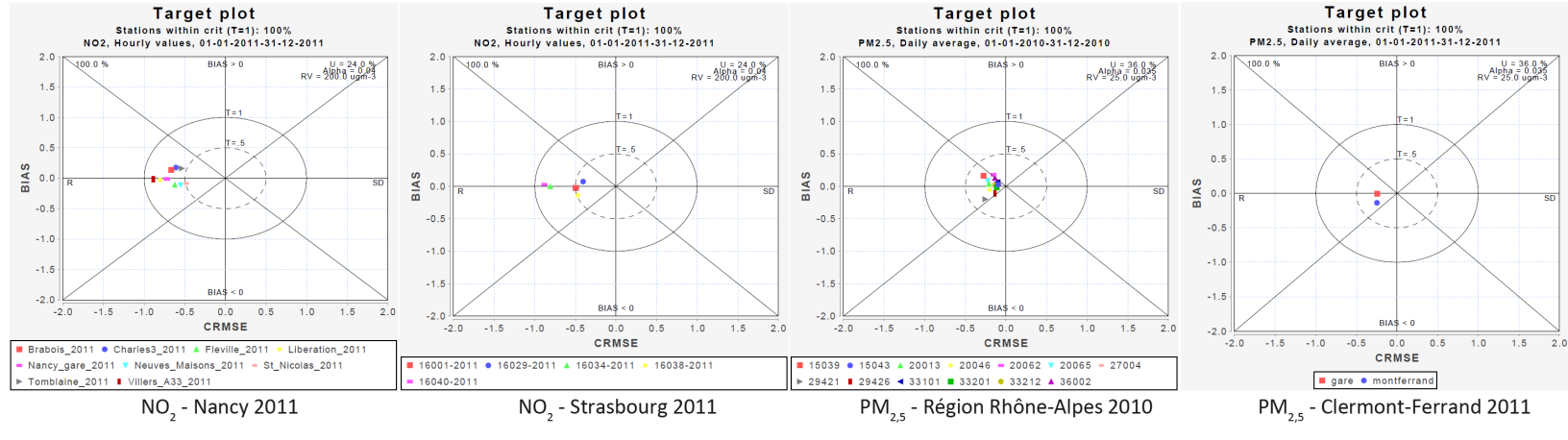

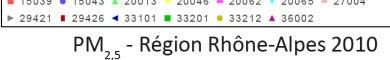

$\mathrm{PM}_{2,5}$ - Clermont-Ferrand 2011
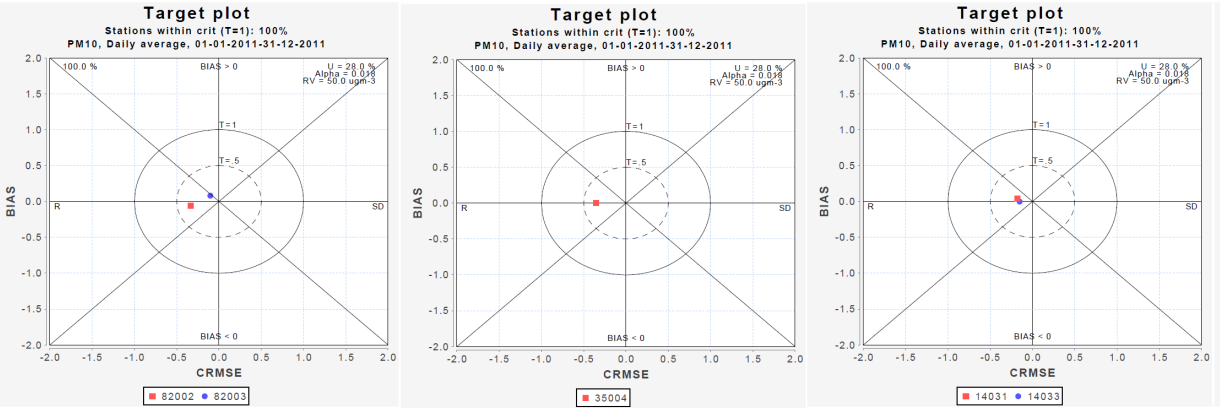

$\mathrm{PM}_{10}$ - Besançon 2011

$\mathrm{PM}_{10}$ - Brive 2011

$\mathrm{PM}_{10}$ - Troyes 2011

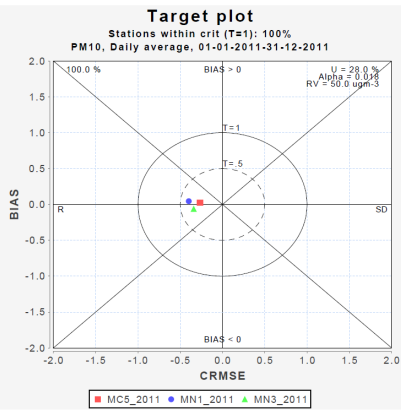

$\mathrm{PM}_{10}$ - Lille 2011 


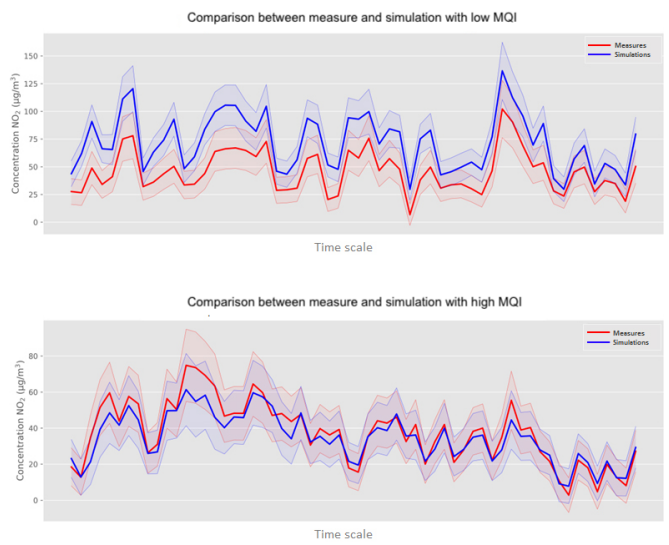




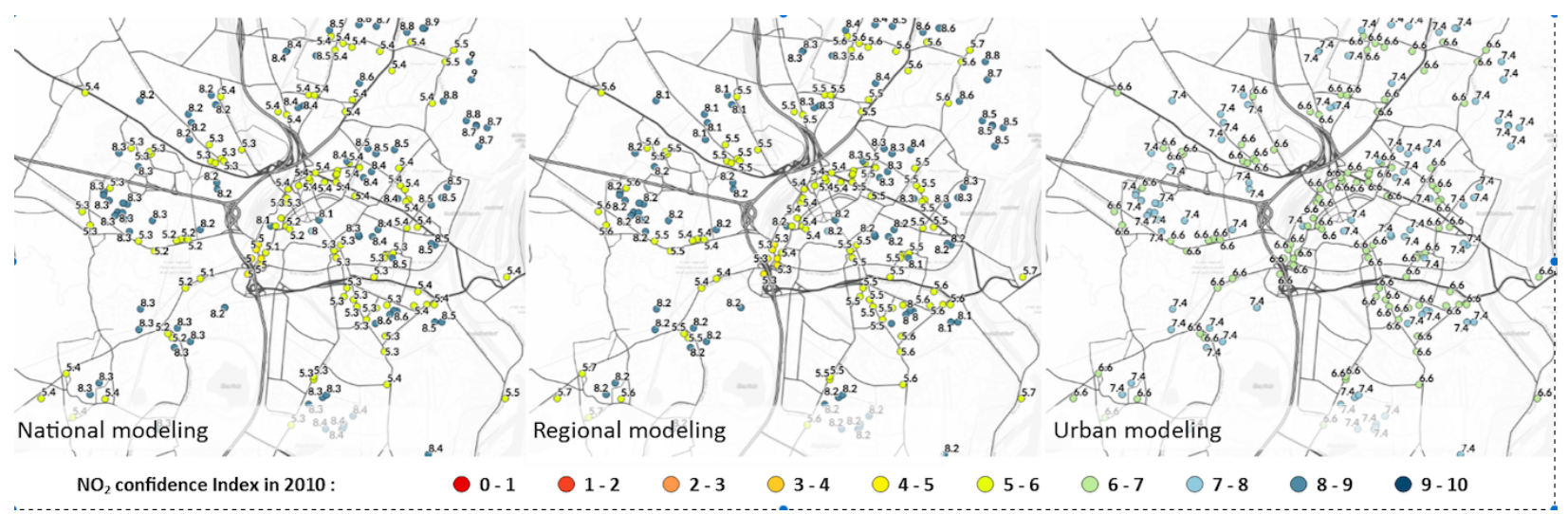




\section{Highlights}

- $\mathrm{NO}_{2}, \mathrm{PM}_{10}$ and $\mathrm{PM}_{2.5}$ exposure during pregnancy for the ELFE mother-child cohort

- Fine spatial (10-200 meters at the urban scale) and temporal resolution for France

- Combination of three dispersion models at the national, regional, and local scale

- Confidence index to choose the best exposure model

- Mean pregnancy exposure was $21 \mu \mathrm{g} / \mathrm{m}^{3}$ for $\mathrm{NO}_{2}, 16 \mu \mathrm{g} / \mathrm{m}^{3}$ for $\mathrm{PM}_{2.5}, 24 \mu \mathrm{g} / \mathrm{m}^{3}$ for $\mathrm{PM}_{10}$ 